\title{
Vegetation of the eastern communal conservancies in Namibia: I. Phytosociological descriptions
}

\begin{tabular}{|c|c|}
\hline \multicolumn{2}{|c|}{$\begin{array}{l}\text { Author: } \\
\text { Ben J. Strohbach }{ }^{1}\end{array}$} \\
\hline \multicolumn{2}{|c|}{$\begin{array}{l}\text { Affiliation: } \\
{ }^{1} \text { School of Natural Resources } \\
\text { and Spatial Sciences, } \\
\text { Polytechnic of Namibia, } \\
\text { Namibia }\end{array}$} \\
\hline \multicolumn{2}{|c|}{$\begin{array}{l}\text { Correspondence to: } \\
\text { Ben Strohbach }\end{array}$} \\
\hline \multicolumn{2}{|c|}{$\begin{array}{l}\text { Email: } \\
\text { bstrohbach@polytechnic. } \\
\text { edu.na }\end{array}$} \\
\hline \multicolumn{2}{|c|}{$\begin{array}{l}\text { Postal address: } \\
\text { Private Bag 13388, } \\
\text { Windhoek, Namibia }\end{array}$} \\
\hline \multicolumn{2}{|c|}{$\begin{array}{l}\text { Received: } 30 \text { Oct. } 2012 \\
\text { Accepted: } 23 \text { May } 2014 \\
\text { Published: } 28 \text { Nov. } 2014\end{array}$} \\
\hline \multicolumn{2}{|c|}{$\begin{array}{l}\text { How to cite this article: } \\
\text { Strohbach, B.J., 2014, } \\
\text { 'Vegetation of the eastern } \\
\text { communal conservancies in } \\
\text { Namibia: I. Phytosociological } \\
\text { descriptions', Koedoe } 56(1) \text {, } \\
\text { Art. \#1116, } 18 \text { pages. http:// } \\
\text { dx.doi.org/10.4102/koedoe. } \\
\text { v56i1.1116 }\end{array}$} \\
\hline \multicolumn{2}{|c|}{$\begin{array}{l}\text { Note: } \\
\text { Additional supporting } \\
\text { information may be found } \\
\text { in the online version of } \\
\text { this article as an Online } \\
\text { Appendix: http://dx.doi. } \\
\text { org/10.4102/koedoe. } \\
\text { v56i1.1116-1. }\end{array}$} \\
\hline \multicolumn{2}{|c|}{$\begin{array}{l}\text { Copyright: } \\
\text { (C) 2014. The Authors. } \\
\text { Licensee: AOSIS } \\
\text { OpenJournals. This wc } \\
\text { is licensed under the } \\
\text { Creative Commons } \\
\text { Attribution License. }\end{array}$} \\
\hline \multicolumn{2}{|l|}{ Read online: } \\
\hline 口ifra & $\begin{array}{l}\text { Scan this QR } \\
\text { code with your } \\
\text { smart phone or } \\
\text { mobile device } \\
\text { to read online. }\end{array}$ \\
\hline
\end{tabular}

The establishment of communal conservancies aims to have the local communities share in the benefits especially of wildlife resources, in this way spearheading the conservation of the environment. The Desert Margins Programme in Namibia aimed to develop vegetation resource data for the Otjituuo, Okamatapati, Ozonahi, African Wild Dog, Otjinene, Epukiro, Otjombinde, Omuramba Ua Mbinda, Eiseb and Ondjou communal conservancies, in order to assist with natural resource planning. For this purpose, a phytosociological survey of this area, with 422 relevés, was conducted during 2004. The data was captured in Turboveg and forms part of the Namibian phytosociological database (GIVD AF-NA-001). The data was split into two, representing two major land forms, the 'hardeveld' and the 'sandveld', respectively. A classification was undertaken using the Modified two-way indicator species analysis (TWINSPAN) procedure. Further refinements, based on field observations and literature sources, were performed using Cocktail procedures. Thirteen vegetation associations were formally described in this article, of which two were subdivided into subassociations. These associations can broadly be grouped into broad-leaved savanna types typical of the central and northern Kalahari of Namibia and microphyll savannas found on the transitions to the Central Plateau. One association, the Burkeo africanae-Pterocarpetum angolensis, forms the southern fringe of the Zambesian Baikiaea Woodlands ecoregion of the World Wildlife Fund, whilst all the other associations fall within the Kalahari Acacia-Baikiaea Woodlands ecoregion. The Combreto collini-Terminalietum sericeae is the most widespread association and dominates the landscape. Threats to the vegetation include overutilisation and regular fires, both of which could easily lead to desertification. This threat is aggravated by global climate change.

Conservation implications: This article described 13 plant associations of the central Kalahari in eastern Namibia, an area hitherto virtually unknown to science. The information presented in this article forms a baseline description, which can be used for future monitoring of the vegetation under communal land use.

\section{Introduction}

Since Namibia's independence there has been a substantial increase in efforts to develop the country's communal farming areas. Many of these areas have been, and still are, subjected to poor and indifferent management practices resulting from a lack of sound ecological (baseline) data and hence a poor understanding especially of the vegetation resource base - its biodiversity, dynamics, possibilities of utilisation and its limitations (Hines 1992; Mendelsohn et al. 2002). This is also the case when looking at the communal lands in eastern Namibia, which consist of what was formerly known as Bushmanland, Hereroland West and Hereroland East. A phytosociological study on the vegetation of Bushmanland (part of the present Tsumkwe district) was conducted by Hines (1992). Information regarding the vegetation of the former Hereroland could thus far only be approximated from the preliminary vegetation map of Namibia (Giess 1998), as well as the Relative homogenous farming areas report (Department Landbou Tegniese Dienste 1979). The above report lists farming possibilities and constraints of the commercial farming area and includes a grazing-capacity map based on expert opinion. This map has been found to be outdated (Espach, Lubbe \& Ganzin 2006; Lubbe 2005) mainly because the concept of carrying capacity has since changed from a fixed rate per area to a biomass concept, which is an (annually changing) estimate of the amount of fodder produced during the previous season's rainfall (Bester 1988; Espach et al. 2006; Espach, Lubbe \& Ganzin 2010). The preliminary vegetation map of Namibia is regarded as relatively accurate as far as the delineation of vegetation types is concerned, but some anomalies have been found. Furthermore, its descriptions of Namibian vegetation types are very basic. Both publications were based on limited observations and some photographic records, but no actual ecological surveys were conducted when they were compiled. Few attempts have since been undertaken to describe the vegetation of Namibia further (Burke \& Strohbach 2000; Strohbach \& Jürgens 2010). 
The target area selected for this study was the former Hereroland, which now consists of communal and emerging commercial farms within the Omaheke and Otjozondjupa regions of central-eastern Namibia. In order to empower the farmers to sustainably utilise their natural resources, especially wildlife resources, the establishment of communal conservancies is promoted in Namibia (Weaver \& Petersen 2008; Weaver \& Skyer 2005). At the start of the study (2004), nine communal conservancies were planned; by 2005, the following conservancies had already been proclaimed: Ozonahi (Okakarara), African Wild Dog (Okandjatu), Otjituuo and Okamatapati. The Ondjou Conservancy (Gam) followed in 2006, whilst the Eiseb, Omuramba Ua Mbinda and Otjombinde Conservancies (the former two forming the 'Eiseb Block' and the latter the 'Rietfontein Block') were only proclaimed in 2011 (Nambian Association of Community Based Natural Resource Management [CBNRM] Support Organisations 2011; Steynberg 2011). Of those included in this study, only the Epukiro and Otjinene farming areas are not yet considered as emerging conservancies (Figure 1).

The goal of the Desert Margins Programme (Namibia) was the conservation and restoration of biodiversity in Namibia's desert margins. One of the major outputs was the establishment of baseline information on natural resources available to local communities in selected areas. In order to establish such baseline information, a survey of the vegetation types was commissioned for these communal conservancies as a baseline of the ecosystems to be managed. This is in line with generally proposed uses of such vegetation descriptions and maps (Brown et al. 2013; Strohbach 2012). The nomenclature throughout this article follows Klaassen and Kwembeya (2013).

\section{Research method and design}

\section{Study area}

The study area consisted of the farming areas of Okakarara, Okondjatu, Otjituuo, Okamatapati, Gam, Eiseb, Rietfontein, Epukiro and Otjinene in the Otjozondjupa and Omaheke regions (Figure 1), covering $57414.72 \mathrm{~km}^{2}$.

\section{Climate}

Very little meteorological data has officially been recorded within the study area. Climate variables for the area have been extrapolated from records collected in Gobabis, Grootfontein, Tsumkwe and Ghanzi (in Botswana). Average long-term annual rainfall ranges from about $325 \mathrm{~mm}$ to $350 \mathrm{~mm}$ in the south-eastern corner (Rietfontein Block) and the westernmost part (around Okakarara) and from about $425 \mathrm{~mm}$ to $450 \mathrm{~mm}$ in the central part of the area roughly from Okondjatu and Otjinene to the Mangetti Dune

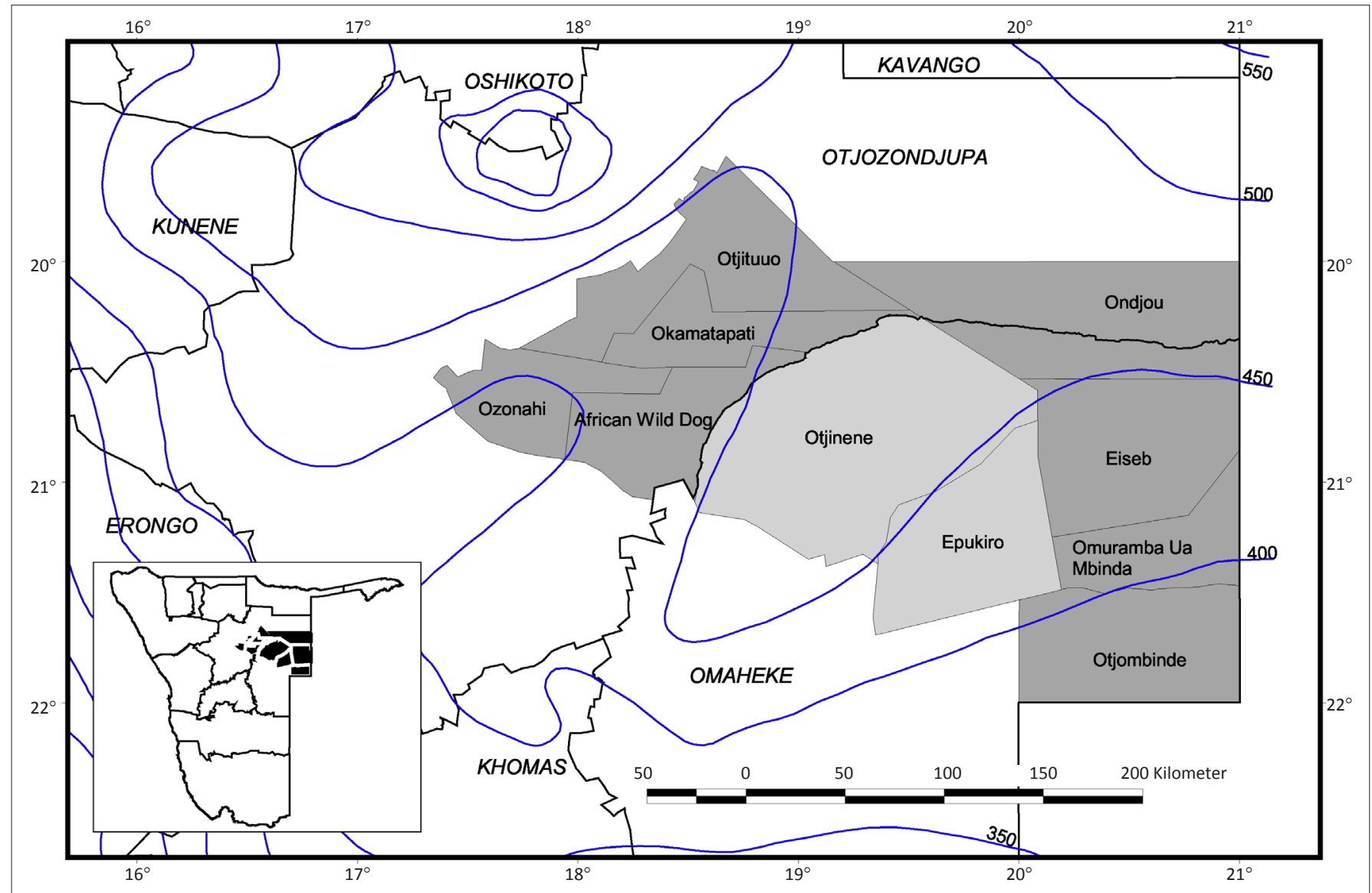

Source: Data for rainfall and administrative regions from Namibian Agricultural Resources Information System, 2001, 'Namibian Agricultural Resources Information System (NARIS), Agro-ecological zoning program', Ministry of Agriculture, Water and Rural Development, Windhoek

FIGURE 1: Overview map of the communal conservancies within the Omaheke and Otjozondjupa regions in Namibia. The average annual rainfall is indicated by the isohyets, with their values in millimetres, indicated on the right. 
(Figure 1). An important aspect of this rainfall is its often erratic nature within the rainfall season and from year to year. Droughts are regarded as common (Botha 1998; Leser 1972; Mendelsohn \& El Obeid 2002).

During winter, mean daily temperatures range from $2.5^{\circ} \mathrm{C}$ (minimum) to $22.2{ }^{\circ} \mathrm{C}$ (maximum) (with 8 frost days) in the southernmost parts of the study area and from about $4.3^{\circ} \mathrm{C}$ (minimum) to $23.6{ }^{\circ} \mathrm{C}$ (maximum) (with 2 frost days) in the northern parts. During summer, mean daily temperatures range from $17.4{ }^{\circ} \mathrm{C}$ (minimum) to $31.8{ }^{\circ} \mathrm{C}$ (maximum) in the southern parts and from $17.9{ }^{\circ} \mathrm{C}$ (minimum) to $30.2{ }^{\circ} \mathrm{C}$ (maximum) in the northern parts. However, daytime temperatures can soar to just below $40.0^{\circ} \mathrm{C}$, especially during November and December (Mendelsohn \& El Obeid 2002).

\section{Landscapes and geology}

The study area is situated on the vast Kalahari System (Geological Survey 1980; Thomas 1988; Mendelsohn et al. 2002; Mendelsohn \& El Obeid 2003). This ancient basin has been gradually filled up with silt and clay sediments and windblown sands during the Tertiary to Quaternary Periods (32-39 Ma) (Geological Survey 1980). The windblown sands dominate the surface soils of the study area. Occasionally, exposed rock formations can be found - these are mainly sandstones, limestones, schists and dolomites of the much older Karoo and Damara Sequences.

The sandy landscapes are generally flat to rolling (with $6^{\circ}-9^{\circ}$ slopes); these plains are incised by omuramba valleys or alternated with vegetated fossil (no longer actively moving) dunes. An omuramba (plural: omiramba) can best be described as a shallow watercourse with no visible gradient (King 1963).

Leser (1972) differentiates between coarse-grained yellow sands, which were found mostly on plains, and finer-grained reddish sands, present especially on the fossil dunes. Apart from the omuramba valleys, which often have exposed or underlying calcretes and limestone ridges, occasional pans formed by the limited runoff in the area have grey clays to grey sands. A more thorough study of the soils and landscapes is presented by Strohbach et al. (2004).

\section{Procedure}

Surveying followed the general method employed for the vegetation survey of Namibia project (Strohbach 2001). Sampling of 422 plots throughout the study area took place during April and May 2004. Owing to the vastness of the area, and the limited access to it, emphasis was placed on the sampling of dominant vegetation types (rather than rare niche types) along roads, tracks and cutlines, following a stratified systematic approach. False colour LandSat Thermatic Mapper (TM) imagery was used for stratification. At each survey plot of $20 \mathrm{~m} \times 50 \mathrm{~m}\left(1000 \mathrm{~m}^{2}\right)$, a Braun-Blanquet relevé was compiled. All occurring vascular plant species were noted down, as well as their typical growth forms and estimated percentage crown cover. Habitat descriptors included: the position by way of a GPS-reading (referenced to WGS84), the landscape, local topography, slope and aspect, lithology, degradation indicators, as well as a photograph. Unknown species and reference specimens were collected, identified and deposited at the National Herbarium of Namibia (WIND).

The relevé data was captured on Turboveg (Hennekens \& Schaminée 2001) and forms part of the Namibian phytosociological database (GIVD ID: AF-NA-001) (Strohbach \& Kangombe 2012; see Dengler et al. 2011). For the original report (Strohbach et al. 2004), this data was classified with PhytoTab (Westfall et al. 1982). The initial study identified three associations, which were represented by a limited number of relevés, but which are known also from other studies (Hines 1992, own unpublished data). For this reason, relevant relevé data available in the Namibian phytosociological database (GIVD ID: AF-NA-001) from the Tsumkwe district (25 relevés from Hines 1992 surveyed on $400 \mathrm{~m}^{2}$ plots) and from the southern Mangetti area near Tsintsabis in the Grootfontein district (five relevés from own unpublished data surveyed on $1000 \mathrm{~m}^{2}$ plots) was extracted and included in the dataset. The final dataset consists of 451 relevés, with 448 species. For the present study the classification was repeated using Juice 7 (Tichý 2002). Total inertia was used as diversity measure, whilst pseudospecies cut levels set at $0 \%, 2 \%, 5 \%$ and $20 \%$, were utilised because the gradients were often very gradual, resulting in strong overlapping of species distribution. For convenience, the dataset was split into two, using the first division of a Modified two-way indicator species analysis (TWINSPAN) classification (Roleček et al. 2009).

The two relevé groups were further classified, again using Modified TWINSPAN with the same settings as before. The highest level of divisions still yielding floristically wellcharacterised clusters was used. After inspection of the results, it was realised that further refinements were necessary on some of the clusters, based on both field observations and previous vegetation descriptions, in particular Cole and Brown (1976), Hines (1992), Leser (1972) and Strohbach et al. (2004). This was performed with Cocktail (Bruelheide 1997; Bruelheide \& Flintrop 1994) using known character species for selection. In several cases, recombinations of clusters as subassociations or even associations were necessary to produce ecological significant results. The fact that such clusters could not be differentiated with diagnostic species but had similar habitat, structure and dominant species composition was taken as criteria for recombination.

Diagnostic species were determined using the phi co-efficient of association (Chytrý et al. 2002). For this calculation the relevé numbers were standardised following Tichý and Chytrý (2006). Species with phi $\geq 40$ were considered as diagnostic and with phi $\geq 60$ as highly diagnostic; however, species with a non-significant fidelity at $\alpha=0.05$ using Fisher's exact test were omitted. Species occurring at least 
with a $60 \%$ frequency were regarded as constant and with at least an $80 \%$ frequency as highly constant.

Further calculations to describe the structure and species richness were performed using the available growth form data and species richness and density. For the calculation of species density (number of species per $1000 \mathrm{~m}^{2}$ ), the relevé data from Hines (1992) was excluded, as these were sampled on $400 \mathrm{~m}^{2}$ plots, not $1000 \mathrm{~m}^{2}$ plots as all other relevés.

\section{Results}

The classification results are depicted in Figure 2 as a dendrogram. The first division of the dataset represents two distinct habitat and physiognomic groupings: the 'sandveld' or broad-leafed savannas on very sandy habitats (265 relevés with 305 species) and the 'hardeveld' ('hard veld') on slightly to very loamy soils, occasionally even shallow rocky substrates with microphyll savannas (186 relevés with 402 species).

Within the hardeveld (Figure 2 top), the second cluster was split into two associations with the aid of Cocktail (Bruelheide 1997; Bruelheide \& Flintrop 1994), using the presence of Felicia clavipilosa subsp. clavipilosa, Lycium bosciifolium, Ptycholobium biflorum subsp. angolensis and Xerophyta humilis versus Combretum imberbe. In addition to differences in composition, these two associations were recognised in the field as different in structure and habitat. A third association (no. 5), based on the dominance (> 5\% cover) of Catophractes alexandri, but the absence of indicator species Eriocephalus luederitzianus and Hyphaene petersiana, was defined also using Cocktail. This is in line with various literature sources, in particular Cole and Brown (1976), Hines (1992), Leser (1972) and Strohbach et al. (2004). The initial clusters 8,9 and 10 could not be differentiated through diagnostic species, only through subtle differences in constant and dominant species. Therefore clusters 9 and 10 were combined as a subassociation (10.2), which, in turn, was combined with cluster 8 (subassocaition 10.1) to form a larger association (10) because of the high similarity in permanent species composition, structure and habitat.

Within the group of relevés representing the broad-leaved savannas, again, Cocktail had to be employed to strengthen cluster 1, based on the presence of Pterocarpus angolensis and Burkea africana. This cluster was also split into two, based on the presence of Schinziophyton rautanenii and Strychnos pungens. These refinements were based on findings from the original study (Strohbach et al. 2004) as well as Hines (1992). Clusters 2 to 5 were recognised as subassociations of a single association, because of the very similar structure, dominance by Terminalia sericea and various Combretum species and similar habitat. In effect, these four subassociations represent a precipitation gradient (Strohbach \& Kutuahuripa submitted).

The full phytosociological table is presented in downloadable form in Online Appendix 1 and, similarly, the synoptic table in Online Appendix 2. The classification yielded 11 communities, of which 10 are formally described associations, following the International Code for Phytosociological Nomenclature (Weber, Moravec \& Theurillat 2000). Species with high fidelity (phi $\geq 60$ ) and high constancy (frequency $\geq 80 \%$ ) are indicated in bold. Structural description follows Edwards (1983), whilst habitat descriptions follow the soil and terrain database (SOTER) terminology (Food and Agricultural Organization [FAO] 1995).

\section{Acacio fleckii-Terminalietum prunioidis ass. nov.}

The type for this association is relevé 1336, sampled on 29 April 2004 at $20^{\circ} 12^{\prime} 40^{\prime \prime}$ S, 20 $26^{\circ} 22^{\prime \prime}$ E. Only two relevés of this association were sampled in the present study area, but this association occurs extensively within the Nyae-Nyae Conservancy further north (Hines 1992). An additional 15 relevés from the Hines (1992) dataset were included in the present dataset. This association is characterised by the diagnostic species Croton gratissimus, Grewia bicolor, Terminalia prunioides, Hibiscus calyphyllus, Talinum arnotii, Searsia marlothii, Combretum apiculatum subsp. apiculatum, Grewia villosa, Barleria senensis, Achyranthes aspera var. sicula, Panicum maximum, Solanum kwebense and Crotalaria flavicarinata. These are constantly associated with Pupalia lappacea, Grewia flavescens, Dichrostachys cinerea, Brachiaria deflexa and Urochloa brachyura. A total of 63 species have been observed in this association, with, on average, 20 species per $1000 \mathrm{~m}^{2}$.

Hines (1992) refers to these thickets as Terminalia prunioides association and describes them as occurring on some sub-outcropping geological features, specifically fold structures (e.g. near Cin Qo) throughout the Nyae-Nyae Conservancy. Bearing out Hines's (1992) findings, these thickets were found on low limestone ridges, mostly covered

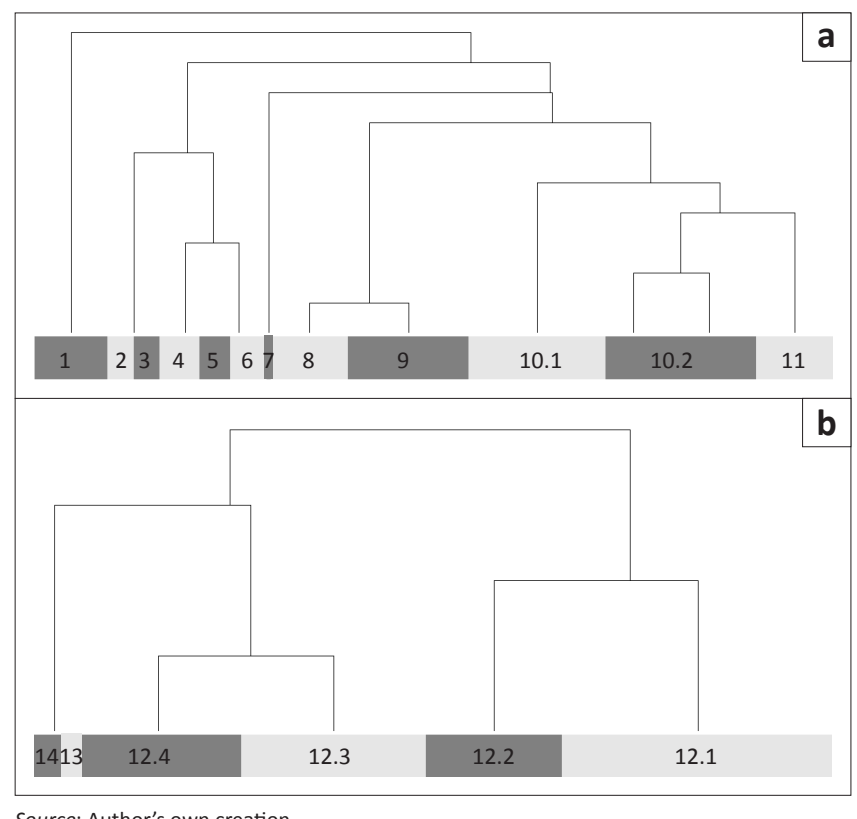

Source: Author's own creation

FIGURE 2: Dendrograms of the classification results of, (a) microphyll savannas and (b) broad-leaved savannas, also indicating refinements to certain clusters performed during data processing. The numbers correspond to the association numbers used in the text. 
by shallow sand deposits with few stones on the surface ( $<1 \%$ cover), north of Gam. Here the altitude ranges between 1110 m.a.s.l. and 1130 m.a.s.l., with generally rolling slopes. The soils are mostly shallow. As a result of the loose sand cover, few or no signs of crusting, but slight to moderate signs of erosion were observed. The thickets sampled in this study are situated near the resource-poor settlements of Gam and showed severe signs of degradation through overgrazing and felling of trees for timber.

Terminalia prunioides dominated the tree layer at between $40 \%$ and $60 \%$. The shrub understorey was, on average, less than $10 \%$, making this association a tall, closed woodland. Grass cover was generally variable, dominated by annual grasses (Figure $3 a$ and Figure 4a). Only two perennial grass species were observed, these being Panicum maximum and Cenchrus ciliaris, indicative of the poor grazing resource these thickets represent. Although this could be attributed to overgrazing in the area, heavy shading by the overstorey would also prevent the growth of good grazing.

\section{Acacio tortilis-Combretetum imberbis ass. nov.}

The type for this association is relevé 1240, sampled on 23 April 2004 at $20^{\circ} 40^{\prime} 57^{\prime \prime}$ S, $17^{\circ} 42^{\prime} 53^{\prime \prime}$ E. Six relevés were classified into this association. It is characterised by the diagnostic species Guilleminea densa, Mollugo nudicaulis, Lotononis listii, Combretum imberbe, Dactyloctenium aegyptium, Alternanthera pungens, Kalanchoe rotundifolia, Corchorus tridens, Zehneria marlothii, Portulaca hereroensis, Aptosimum glandulosum and Chloris virgata. These are constantly associated with Eragrostis porosa, Ziziphus mucronata, Tragus berteronianus, Eragrostis trichophora, Chamaesyce inaequilatera, Acrotome species and Acacia mellifera subsp. detinens. A total of 91 species were observed here, with, on average, 37 species per $1000 \mathrm{~m}^{2}$.

Very striking are the tall Combretum imberbe (Leadwood) trees interspersed with smaller trees of Acacia tortilis in this association. The understorey of shrubs is variable, mostly less than $10 \%$ cover, making this a tall, semi-open bushland (Figure $3 \mathrm{~b}$ and Figure $4 \mathrm{~b}$ ). The Omuramba Omatako near Okakarara has a distinct wetland characteristic, with Eragrostis rotifer present in two, and Schoenoplectus senegalensis and Marsilea macrocarpa present in one, of the sites - all species common in areas with seasonal standing water. Although some of the patches are drier and have a higher cover of grasses, including some perennial grasses, this syntaxon is to be regarded as having a low grazing capacity. If left ungrazed during the rainy season (which it was evidently not), this could, like the oshanas in the central north, be valuable winter grazing. The Omuramba Omatako is at an altitude of between 1290 m.a.s.l. and 1310 m.a.s.l. south of Okakarara and it flows in a north-easterly direction towards Otjituuo. The slopes are flat to gently undulating, whilst the soils are strongly crusted. At one of the sites, signs of selective wood harvesting of Combretum imberbe was observed.

\section{Ptycholobio biflori-Acacietum luederitzii ass. nov.}

The type for this association is relevé 1233, sampled on 23 April 2004 at $20^{\circ} 42^{\prime} 01^{\prime \prime}$ S, 17³5'49" E. Six relevés were classified into this association. It is characterised by the diagnostic species Felicia clavipilosa subsp. clavipilosa, Lycium bosciifolium, Hibiscus micranthus, Xerophyta humilis, Ptycholobium biflorum subsp. angolensis, Barleria lancifolia, Pavonia burchellii, Chloris virgata, Hibiscus vitifolius, Kyphocarpa angustifolia, Calostephane divaricata, Ocimum americanum var. americanum, Solanum delagoense, Barleria senensis, Aristida rhiniochloa and Dactylotenium aegyptium. These are constantly associated with Tragus berteronianus, Eragrostis trichophora, Acacia mellifera subsp. detinens, Acacia luederitzii, Ziziphus mucronata, Kleinia longiflora, Grewia flava, Gisekia africana, Eragrostis porosa, Eragrostis dinteri, Brachiaria deflexa, Boscia albitrunca, Aristida adscensionis, Pupalia lappacea, Pogonarthria fleckii, Grewia flavescens, Dicoma tomentosa, Cleome rubella, Asparagus cooperi and Aristida congesta subsp. congesta. A total of 89 species were observed here, with, on average, 48 species per $1000 \mathrm{~m}^{2}$.

This association has a consistent tree layer of about $6 \mathrm{~m}-8 \mathrm{~m}$ in height with a cover of about $12 \%$. The shrub layer reaches a cover of about $24 \%$, thus making the structure a short, semiopen thicket (Figure $3 \mathrm{c}$ and Figure $4 \mathrm{c}$ ).

The Ptycholobio biflori-Acacietum luederitzii occurs typically on the floodplains around the Omuramba Omatako, south of Okakarara in the Ozonahi Conservancy, characterised by the erosion plains around the Omatako Omuramba throughout its catchment. These floodplains are gently undulating and generally at an altitude of 1290 m.a.s.l. - 1330 m.a.s.l. The soils are shallow, with a hardpan layer at a depth of $30 \mathrm{~cm}$, and generally strongly crusted. Only slight sheet erosion was observed. These floodplains are (relatively) undisturbed; although, a few show signs of bush encroachment. On one occasion severe overgrazing was observed near a village.

Grazing value is low, with only two perennial grasses (Eragrostis trichophora and Aristida congesta) being found consistently. Both are low producers of biomass, whilst Aristida congesta is also known as generally hard and unpalatable (Müller 2007). The annual grass layer is dominated by Eragrostis porosa and Aristida rhiniochloa. The latter can produce fairly high amounts of biomass, but is a very hard grass with a strong, pungent seed. Both these species are regarded as unpalatable. The poor grazing condition is aggravated by the consistent occurrence of the poisonous Geigeria ornativa.

\section{Eragrostio echinocloideae-Eriocephaloetum luederitziani ass. nov.}

The type for this association is relevé 1180, sampled on 16 April 2004 at $21^{\circ} 34^{\prime} 16^{\prime \prime}$ S, 20 $36^{\prime} 14^{\prime \prime}$ E. Ten relevés were classified into this association. Diagnostic species for this association are Oropetium capense, Eragrostis echinochloidea, Eriocephalus luederitzianus, Enneapogon 
desvauxii, Salsola tuberculata, Panicum coloratum, Cynodon dactylon, Jamesbrittenia atropurpurea subsp. atropurpurea, Eragrostis truncate and Chenopodium petiolariforme. These are constantly associated with Eragrostis porosa, Hermannia modesta, Asparagus cooperi, Acacia hebeclada subsp. hebeclada, Tragus berteronianus, Stipagrostis uniplumis var. uniplumis and Grewia flava. A total of 86 species were observed here, with, on average, 27 species per $1000 \mathrm{~m}^{2}$.

With a variable, but very low, tree cover and low shrubs between $40 \mathrm{~cm}$ and $120 \mathrm{~cm}$ in height dominating the landscape, the structure can best be described as a low, semi-open shrubland (Figure 3d and Figure 4d).

This association occurs in omiramba with heavier loamy and clay soils, as well as a pan near Otjutuuo in the far north. The soils are often strewn, up to $15 \%$, with calcrete fragments of sizes ranging from gravel to large stones. Rocks were even found on one site. The soil surface is moderately to strongly crusted, showing signs of slight sheet erosion. The slopes are generally flat to undulating. These omiramba occur at altitudes of 1180 m.a.s.l. - 1330 m.a.s.l.

Although the Eragrostio echinocloideae-Eriocephaloetum luederitziani occasionally has a very high cover of grasses, this is not the norm. The dominant grass species are Eragrostis echinochloidea, Eragrostis porosa, Enneapogon desvauxii, Tragus racemosus and Stipagrostis uniplumis var. uniplumis. However, only the latter species is a bulk biomass producer. Enneapogon desvauxii in particular is a very short grass, about $5 \mathrm{~cm}$ high, often forming a fairly dense cover. It is a fast grower, producing leaves and seed within a short period of time (thus the vernacular name 'Agt dae gras' [eight day grass]). The combination of species - Enneapogon desvauxii, Eragrostis echinochloidea, Eriocephalus luederitzianus and Salsola tuberculata - is evident of a harsh microclimate dictated by soil conditions (high $\mathrm{pH}$ and/or sodic). The grazing production in this habitat is thus low and the grazing capacity must equally be regarded as low.

\section{Acacio melliferae-Catophractetum alexandri ass. nov.}

The type for this association is relevé 1260, sampled on 24 April 2004 at $20^{\circ} 35^{\prime} 44^{\prime \prime}$ S, 18 $18^{\circ} 05^{\prime} 26^{\prime \prime}$ E. Twenty-one relevés were classified into this association, which is characterised by the occurrence of Catophractes alexandri as diagnostic species. This species also dominates the landscape with an average $20 \%-40 \%$ cover. It is constantly associated with Grewia flava, Acacia mellifera subsp. detinens, Eragrostis porosa, Clerodendrum ternatum, Urochloa brachyura, Stipagrostis uniplumis var. uniplumis, Rhigozum brevispinosum, Tragus berteronianus, Melinis repens subsp. grandiflora, Otoptera burchellii, Kleinia longiflora, Boscia albitrunca, Gisekia africana and Aristida congesta subsp. congesta. A total of 132 species were observed in this association, with, on average, 36 species per $1000 \mathrm{~m}^{2}$.

The Acacio melliferae-Catophractetum alexandri is strikingly dominated by more or less dense stands of Catophractes alexandri. Trees are scarce to totally absent, whilst an average of $40 \%-60 \%$ shrub cover of between $1 \mathrm{~m}$ and $3 \mathrm{~m}$ in height is characteristic, thus it can be described as a tall, closed shrubland (Figure $3 \mathrm{e}$ and Figure 4e).

Hines (1992) described a similar vegetation unit (the Catophractes alexandri subassociation of the Croton gratissimusGrewia flava association) for the Nyae-Nyae Conservancy. This unit is described as occuring on soils with shallow underlying calcretes. As localised stands of dense Catophractes alexandri can be found throughout northern Namibia, always on relatively shallow calcrete soils, this community is recognised as a separate association, even though it is closely related to the Stipagrostio uniplumis-Acacietum melliferae.

Catophractes alexandri is regarded a typical indicator for petric Calcisols (i.e. shallow loamy soils with calcretes) (Cole \& Brown 1976; Hines 1992). Such soils occur in some of the omiramba, in interdunal valleys and around larger pans and depressions. Generally, the slopes are flat to gently undulating, at altitudes of between 1220 m.a.s.l. and $1450 \mathrm{~m}$.a.s.l. The soil surface is often covered, but never more than $2 \%$, with fragments of the underlying calcretes that vary in size from small (gravel) to large (stones). Leser (1972) describes similar soil conditions for his Catophractes alexandri shrublands along the Black Nossob. The soil surface was also observed to be moderately to strongly crusted, showing signs of slight sheet erosion. In one case, slight rill erosion was observed. Bush encroachment is a common disturbance.

The most prominent perennial grasses are Stipagrostis uniplumis, Aristida congesta, Eragrostis rigidior, Eragrostis trichophora and Cenchrus cilliaris. These are all known to be neither highly palatable, nor indicators of good veld (Müller 2007). Most grass species are annuals and also typical pioneer or subclimax species. It is, however, commonly believed that the grazing on these calcareous soils is sweeter and more nutritional, thus the quality of grazing is considered moderate.

\section{Acacio melliferae-Hyphaenetum petersianae ass. nov.}

The type for the Acacio melliferae-Hyphaenetum petersianae is relevé 1403, sampled on 26 April 2004 at 19³7'50" S, $18^{\circ} 31^{\prime} 58^{\prime \prime}$ E. Ten relevés were classified into this association. It is characterised by the diagnostic species Hyphaene petersiana, Enneapogon scoparius, Triraphis purpurea, Combretum hereroense, Peltophorum africanum, Sporobolus ioclados, Acalypha segetalis, Enneapogon desvauxii, Limeum arenicolum, Aristida stipoides, Tragus racemosus, Eragrostis annulata, Elaeodendron transvaalense, Brachiaria deflexa, Terminalia prunioides and Seddera suffruticosa. These are constantly associated with Acacia mellifera subsp. detinens, Eragrostis porosa, Stipagrostis uniplumis var. uniplumis, Pogonarthria fleckii, Eragrostis trichophora, Aristida adscensionis, Urochloa brachyura, Grewia flavescens, Grewia flava, Gisekia africana, Geigeria ornativa, Commiphora pyracanthoides, Asparagus cooperi, Aristida rhiniochloa and Acacia luederitzii. A total of 112 species were observed here, with, on average, 44 species per $1000 \mathrm{~m}^{2}$. 
The typical structure is a tall, moderately closed bushland, with a tree layer varying between $7 \mathrm{~m}$ and $12 \mathrm{~m}$ in height, reaching a cover of $5 \%$, with shrubs covering about $45 \%$ of the landscape (Figure $3 \mathrm{f}$ and Figure 4f).

The Acacio melliferae-Hyphaenetum petersianae forms the extensive Palmolakte ['palm plains'] of the southern Grootfontein district, extending into the north-western Otjituuo Conservancy. But here, in the vicinity of the Omuramba Omatako, it has a distinct wetland character, thus resembling the Parkiesveld found near Maroelaboom. The presence of Elaeodendron transvaalense, Eragrostis aspera and Sporobolus iocladus are typical indicators of this wetland character. The plains are gently undulating to undulating, at an altitude of between 1220 m.a.s.l. and 1260 m.a.s.l. The soils are generally shallow to very shallow on calcrete and/or limestone, with a calcrete fragment cover of up to $40 \%$ on the soil surface. The surface is also moderately to strongly crusted, occasionally with signs of slight sheet erosion. Bush encroachment, often severe, is a common problem here, as it is in the Karstveld in general.

The grazing condition is low, with only two perennial grasses (Eragrostis trichophora and Stipagrostis uniplumis) occurring consistently, but at a very low abundance, at the sample sites. Some of the annual grasses found here are known to be palatable, but all are low biomass producers, whilst many of them are also shade grasses and difficult to reach under the trees and shrubs where they grow.

\section{The Panicum gilvum-Marsilea vlei community}

The vleis are represented only by one relevé, which is regarded as inadequate to warrant a formal description of these wetland grasslands as an association. However, for the record, the following is presented: characteristic for this association are the species Vahlia capensis, Schoenoplectus muricinux, Pycreus macrostachyos, Panicum gilvum, Marsilea nubica var. gymnocarpa, Lindernia parviflora, Diandrochloa pusilla, Cyperus species, Portulaca kermesina, Dactyloctenium giganteum, Kohautia virgata, Lindneria clavata, Schoenoplectus senegalensis, Marsilea macrocarpa, Ipomoea hochstetteri, Eragrostis rotifer, Panicum maximum, Ipomoea coptica and Eragrostis biflora.

The general structure of these vleis is as follows (Figure 4g): within the matrix of surrounding vegetation (mostly the Stipagrostio uniplumis-Acacietum melliferae) is a fringe of dense Acacia luederitzii trees, in combination with tall shrubs such as Acacia mellifera subsp. detinens, Acacia hebeclada subsp. hebeclada and Ziziphus mucronata surrounding the waterholding depression. This fringe generally has the nature of a thicket, with a number of shade-loving grasses (e.g. Panicum maximum) and various mesophylic to hydrophylic forbs growing in the herb layer. At a point towards the centre of the depression (point of semi-permanent waterlogging?) the thicket fringe stops entirely, making way for a grassland dominated by Eragrostis rotifer. Various hydrophylic forbs grow in the substratum, for example Lindernia parvifolia. As the soil gets moister, various Cyperaceae (Schoenoplectus, Pycreus species), some Marsilea species and Diandrochloa pusillia occur. These reach well into the standing water. In the shallow standing water, Marsilea species dominate, being replaced by Panicum gilvum in the deep standing water (Figure 4g). Occasionally water plants such as Aponogeton desertorum, Lasiopogon species and even Nymphaea species occur in the deeper pans (personal observations in the Grootfontein district). Here, Panicum gilvum is also generally replaced by Echionochloa species. In the surveyed pan, however, these were not present.

Similar vleis have been reported to be widespread throughout the northern Kalahari (Hines 1993), without any detailed floristic description. These vleis are important temporal water sources and centres of biodiversity (especially faunal diversity) in the landscape. In the dry season, the remains of Panicum gilvum and other grasses should form valuable, although very limited, grazing resources.

\section{Eragrostio rigidioris-Urochloaetum brachyurae ass. nov.}

The type for this association is relevé 1322, sampled on 28 April 2004 at $20^{\circ} 25^{\prime} 10^{\prime \prime}$ S, $19^{\circ} 49^{\prime} 18^{\prime \prime}$ E. Seventeen relevés were classified into this association. Diagnostic of this is the occurrence of Brachiaria nigropedata, Eragrostis rigidior, Schmidtia pappophoroides, Diospyros lycioides and Cynanchum orangeanum. These are constantly associated with Urochloa brachyura, Stipagrostis uniplumis var. uniplumis, Vernonia poskeana, Bulbostylis hispidula, Aristida congesta subsp. congesta, Grewia flava, Sesamum capense, Otoptera burchellii, Melinis repens subsp. grandiflora, Eragrostis trichophora, Cleome rubella, Boscia albitrunca, Ziziphus mucronata, Pogonarthria fleckii, Oxygonum alatum, Lonchocarpus nelsii, Heliotropium steudneri, Gisekia africana, Dichrostachys cinerea, Clerodendrum ternatum and Acacia hebeclada subsp. hebeclada. A total of 125 species were observed here, with, on average, 40 species per $1000 \mathrm{~m}^{2}$.

Tree cover is virtually absent, whilst the shrub cover is generally absent or very low. If shrubs are present, their cover is below 20\%. Small dense patches of Tarchonanthus camphoratus or Acacia hebeclada subsp. hebeclada in particular may occasionally be found, usually where water accumulates during the rainy season. Accordingly, this association is best described as a tall, semi-open shrubland with a strong grassland character (Figure $3 g$ and Figure $4 \mathrm{~h}$ ). The Eragrostio rigidioris-Urochloaetum brachyurae typically occurs in sandy omiramba crossing through the study area, if not disturbed by overgrazing. The altitude ranges between 1330 m.a.s.l. in the west to 1150 m.a.s.l. in the east. The slopes are generally flat to undulating. Soil depth is moderately deep, with moderate to strong soil crusting present. Slight sheet erosion is widespread.

This association forms a potentially good source of grazing especially because few poisonous plants are present. The biggest threats to these pastures are settlements along the linear pathways through the sandy plains. Generally, 
settlements lead to localised overgrazing in the omiramba, often resulting in the almost exclusive presence of weedy species such as Sida cordifolia.

\section{Tarchonantho camphorati-Acacietum eriolobae ass. nov.}

The type for this association is relevé 1558, sampled on 06 May 2004 at $21^{\circ} 14^{\prime} 14^{\prime \prime}$ S, $19^{\circ} 01^{\prime} 16^{\prime \prime}$ E. Twenty-two relevés were classified into this association, which is characterised by the diagnostic species Tylosema esculentum, Elephantorrhiza elephantina, Ozoroa paniculosa, Ipomoea oblongata, Dicoma schinzii and Limeum fenestratum. These are constanly associated with Stipagrostis uniplumis var. uniplumis, Grewia flava, Dichrostachys cinerea, Acacia mellifera subsp. detinens, Acacia erioloba, Vernonia poskeana, Gisekia africana, Pogonarthria fleckii, Melinis repens subsp. grandiflora, Acacia fleckii, Urochloa brachyura, Eragrostis rigidior, Aristida congesta subsp. congesta, Otoptera burchellii, Bulbostylis hispidula, Oxygonum alatum, Eragrostis porosa and Eragrostis dinteri. A total of 111 species were observed in this association, with, on average, 39 species per $1000 \mathrm{~m}^{2}$.

The characteristic Acacia erioloba occurs here mainly as tall shrub and occasionally as short to tall trees. Thus the typical structure is a short, moderately closed shrubland within the study area (Figure 3h and Figure 4i). Leser (1972) describes an Acacia giraffae-Terminalia sericea-Grewia flava-Tarchonanthus camphoratus association for the south-western part of the sandveld - that is, the area south and west of Otjinene towards Summerdown and Steinhausen. Here, Acacia erioloba (syn. = Acacia giraffae) occurs as a dominant tree, typical for the Camelthorn savanna sensu Giess (1998). It is clear that the relevés sampled from this association within the present study are along the northern fringe, thus not displaying the characteristic structure.

The grazing is dominated by the two relatively hard, bulkproducing species, Stipagrostis uniplumis var. uniplumis and Eragrostis rigidior. Schmidtia pappophoroides, Digitaria seriata, Anthephora pubescens and Brachiaria nigropedata are occasionally present as palatable species. Grazing trails at the Sandveld Research Station near Drimiopsis indicate that the latter three species could contribute a far higher percentage to the grazing production (Bester \& Reed 2003; Bester et al. 2003a, 2003b, 2003c). The poisonous species Elephantorrhiza elephantina and Gnidia polycephala are commonly found, indicating, together with the relatively low occurrence of palatable species, that the grazing within the study area has been degraded and, at present, produces only moderately as subclimax.

\section{Stipagrostio uniplumis-Acacietum melliferae ass. nov.}

The type for this association is a subassociation, the Stipagrostio uniplumis-Acacietum melliferae typicum. Fifty-nine relevés were classified within this association. This association has no diagnostic species, but is typified by the constant occurrence of Acacia mellifera subsp. detinens, Grewia flava, Urochloa brachyura, Boscia albitrunca, Stipagrostis uniplumis var. uniplumis, Grewia flavescens, Tephrosia burchellii, Dichrostachys cinerea, Rhigozum brevispinosum, Ehretia alba, Talinum crispatulum, Evolvulus alsinoides, Acacia luederitzii, Melinis repens subsp. grandiflora, Eragrostis rigidior, Gisekia africana, Clerodendrum ternatum, Tragus berteronianus, Kleinia longiflora and Bulbostylis hispidula. Based on habitat differences, this association can be subdivided into two subassociations.

\subsection{Stipagrostio uniplumis-Acacietum melliferae rhigozetosum brevispinosi subass. nov.}

The type for this subassociation is relevé 1377, sampled on 18 April 2004 at $20^{\circ} 53^{\prime} 14^{\prime \prime}$ S, $20^{\circ} 03^{\prime} 36^{\prime \prime}$ E. Thirty relevés were classified into this subassociation, which is characterised by the diagnostic species Eragrostis lehmanniana, Crotalaria sphaerocarpa and Ipomoea magnusiana. These are constantly associated with Boscia albitrunca, Urochloa brachyura, Acacia mellifera subsp. detinens, Grewia flava, Rhigozum brevispinosum, Vernonia poskeana, Stipagrostis uniplumis var. uniplumis, Tephrosia burchellii, Grewia flavescens, Eragrostis rigidior, Dichrostachys cinerea, Oxygonum alatum, Ehretia alba, Bulbostylis hispidula, Melinis repens subsp. grandiflora, Evolvulus alsinoides and Acacia luederitzii. A total of 141 species were observed here, with, on average, 46 species occurring per $1000 \mathrm{~m}^{2}$.

Trees do occur in this subassociation, but generally at very low cover. With a high shrub cover, this subassociation is best described as a short, moderately closed bushland (Figure $3 i$ and Figure 4j). With a highly variable grass cover, this subassociation has a moderate grazing capacity.

Stipagrostio uniplumis-Acacietum melliferae rhigozetosum brevispinosi is a typical ecotonal vegetation type towards sandy soils, fringing the Stipagrostio uniplumis-Acacietum melliferae typicum on more loamy soils. This is also evident from the species composition, with its numerous psammophyll species. This subassociation occurs on sand drift or 'hardeveld' plains (i.e. plains with more loamy soils), with moderately deep to very deep soils and weak surface crusting. Bush encroachment is a common disturbance. The altitude of these plains ranges between 1030 m.a.s.l. and 1470 m.a.s.l. Slopes vary between flat and undulating, whilst the average annual rainfall varies between $400 \mathrm{~mm}$ and $500 \mathrm{~mm}$.

\subsection{Stipagrostio uniplumis-Acacietum melliferae typicum subass. nov.}

The type for this subassociation is releve 1285, sampled on 25 April 2004 at $20^{\circ} 06^{\prime} 22^{\prime \prime}$ S, 18³1'18" E. Twenty-nine relevés were classified into this subassociation, which features no diagnostic species, but can be recognised according to the following constant species: Grewia flava, Acacia mellifera subsp. detinens, Dichrostachys cinerea, Stipagrostis uniplumis var. uniplumis, Grewia flavescens, Tephrosia burchellii, Urochloa brachyura, Kleinia longiflora, Boscia albitrunca, Tragus berteronianus, Eragrostis porosa, Ehretia alba, Talinum crispatulum, Rhigozum brevispinosum and Pogonarthria fleckii. A total of 128 species were observed in this subassociation, with, on average, 38 species per $1000 \mathrm{~m}^{2}$. This subassociaton is the type for Stipagrostio uniplumis-Acacietum melliferae. 
Although some trees are present, their cover was found to be very variable. However, the shrub component is very consistent, with a cover of $40 \%-50 \%$ and a height of $3 \mathrm{~m}-5 \mathrm{~m}$, thus forming a high, moderately closed bushland sensu Edwards (1983) (Figure 3j and Figure 4k).

The Stipagrostio uniplumis-Acacietum melliferae typicum occurs on plains, interdunal valleys ('streets') and sand drift plains throughout the study area. Slopes range from flat to undulating. The altitude of these plains ranges from 1120 m.a.s.l. to 1460 m.a.s.l. The soils are mostly sandy and deep, only occasionally with signs of calcretes. The soil surface is normally crusted, ranging from moderate to strong. As in Stipagrostio uniplumis-Acacietum melliferae rhigozetosum brevispinosi, bush encroachment is also a widespread problem.

This subassociation has a very high diversity of grass species.The most consistent and abundant grass species is Stipagrostis uniplumis var. uniplumis (average cover 12\%). All other grasses with a high abundance are annual species, all regarded as pioneer or subclimax species. A large variety of poisonous plants occur here, with the biggest threat being Geigeria ornativa, occurring on $24 \%$ of all sites. With this very variable, very pioneer-like grass cover and high number of poisonous plants, grazing is regarded as being moderate.

\section{Terminalio sericeae-Acacietum eriolobae ass. nov.}

The type for this association is relevé 1544, sampled on 05 May 2004 at $21^{\circ} 02^{\prime} 03^{\prime \prime}$ S, $18^{\circ} 20^{\prime} 13^{\prime \prime}$ E. Seventeen relevés were classified into this association, which is characterised by the diagnostic species Bauhinia petersiana subsp. macrantha, Terminalia sericea, Megaloprotachne albescens and Eragrostis dinteri. These are constantly associated with Melinis repens subsp. grandiflora, Grewia flavescens, Acacia mellifera subsp. detinens, Urochloa brachyura, Stipagrostis uniplumis var. uniplumis, Acacia fleckii, Tephrosia burchellii, Dichrostachys cinerea, Boscia albitrunca, Grewia flava, Acrotome spp., Acacia erioloba, Rhigozum brevispinosum, Pogonarthria fleckii, Gisekia africana, Eragrostis trichophora, Pollichia campestris, Kyphocarpa angustifolia, Evolvulus alsinoides, Eragrostis porosa, Dicoma schinzii and Commiphora angolensis. A total of 120 species were observed here, with, on average, 42 species per $1000 \mathrm{~m}^{2}$.

With Acacia erioloba trees being the most prominent species, this association can best be described as a short, moderately closed bushland (Figure 3k and Figure 4l). The Terminalio sericeae-Acacietum eriolobae resembles the Terminalia sericea-Acacia giraffae-Grewia flava association described for the north-eastern sandveld area (Leser 1972) and is thus a typical example of the Camelthorn savanna of the Central Kalahari sensu Giess (1998). The dominance of Aristida stipitata and Terminalia sericea demonstrates the nearness of this association to that of Combreto collini-Terminalietum sericeo. These bushlands are to be seen as an ecotone between the broad-leaved savannas to the north and east and the microphyll Thornbush savannas to the south and west.
This bushland association occurs on gently undulating to undulating plains and sand drift plains and even on interdunal streets at an altitude of between 1020 m.a.s.l. and 1490 m.a.s.l. Soil depth varies, but is mostly moderately deep to very deep. Surface crusting is variable - from uncrusted to moderately and even strongly crusted. Likewise, erosion varies between slight to moderate wind erosion and slight to moderate sheet erosion.

The typical poisonous plants for this association are Elephantorrhiza elephantina and Gnidia polycephala. Both are more or less equally frequent. Occasionally, both Dichapetalum cymosum and Geigeria ornativa also occur the former as remnant from the more mesic broad-leaved savanna, the latter as an indicator of degradation. The medicinal plant Harpagophytum procumbens occurs in small patches throughout this vegetation type, but densities are too low to warrant economic exploitation.

\section{Combreto collini-Terminalietum sericeae ass. nov.}

The type for this association is a subassociation, Combreto collini-Terminalietum sericeae typicum. A total of 243 relevés were classified into this association. The Combreto colliniTerminalietum sericeae is characterised by the diagnostic species Grewia flava, Urochloa brachyura, Rhigozum brevispinosum, Eragrostis rigidior, Acacia mellifera subsp. detinens, Merremia verecunda, Rhynchosia totta, Dicoma schinzii, Cleome rubella, Acacia fleckii, Aristida congesta subsp. congesta, Requienia sphaerosperma and Indigofera bainesii. These are constantely associated with Terminalia sericea, Stipagrostis uniplumis var. uniplumis, Grewia flavescens, Melinis repens subsp. grandiflora, Tephrosia burchellii, Bauhinia petersiana subsp. macrantha, Vernonia poskeana, Combretum collinum, Lonchocarpus nelsii, Xenostegia tridentata subsp. angustifolia, Bulbostylis hispidula, Megaloprotachne albescens, Phyllanthus pentandrus, Gisekia africana, Commiphora angolensis, Acrotome spp., Dichrostachys cinerea, Oxygonum alatum and Digitaria seriata; in absence of the diagnostic species of the Burkeo africanae-Pterocarpetum angolensis and Terminalio sericeaeSchinziophytetum rautanenii.

This association covers most of the landscape of the eastern communal areas. Owing to slight differences in habitat (mainly rainfall variability but also, to a lesser extent, soil depth and loam content of the sand), four subassociations can be recognised.

Livestock is equally dependant on grazing as on browse. A widespread threat to livestock farming in this area is the poisonous plant Dichapetalum cymosum ('magou', 'gifblaar'), which is known to increase under conditions of overgrazing and disturbance (Bester 1989; De Sousa Correia \& Van Rensburg 2000; Van Eck 2000).

\subsection{Combreto collini-Terminalietum sericeae acacietosum melliferae subass. nov.}

The type for this subassociation is relevé 1455, sampled on 01 May 2004 at $21^{\circ} 31^{\prime} 43^{\prime \prime}$ S, 20 $0^{\circ} 59^{\prime} 55^{\prime \prime}$ E. Ninety relevés 
were classified into this subassociation. Combreto colliniTerminalietum sericeae acacietosum melliferae is characterised by the diagnostic species Acacia mellifera subsp. detinens, Dicoma schinzii, Grewia flava, Aristida congesta subsp. congesta and Requienia sphaerosperma. These are constantly associated with Terminalia sericea, Urochloa brachyura, Tephrosia burchellii, Grewia flavescens, Stipagrostis uniplumis var. uniplumis, Melinis repens subsp. grandiflora, Acacia fleckii, Vernonia poskeana, Dichrostachys cinerea, Bauhinia petersiana subsp. macrantha, Bulbostylis hispidula, Phyllanthus pentandrus, Combretum collinum, Gisekia africana, Xenostegia tridentata subsp. angustifolia, Ipomoea hackeliana, Oxygonum alatum, Commiphora angolensis, Acrotome spp. and Phylenoptera nelsii. A total of 153 species were observed here, with, on average, 40 species per $1000 \mathrm{~m}^{2}$.

The structure is best described as a short, moderately closed bushland (Figure 31 and Figures $4 \mathrm{~m}$ and $4 \mathrm{n}$ ). The variable grass cover often observed in this subassociation is most likely the result of the severe overgrazing, often resulting in bush encroachment. The grass layer is dominated by the annual Megaloprotachne albescens and Urochloa brachyura, with Stipagrostis uniplumis var. uniplumis and Eragrostis trichophora being the main perennial species. At best, the grazing capacity is poor to mediocre.

This subassociation forms a patchy ecotone to the Thornbush savannas to the south and west, probably because of localised, less favourable soil-moisture regimes (either from higher runoff on the slopes of omiramba, or more xeric soils). The altitude ranges between 1200 m.a.s.l. in the east and north to 1500 m.a.s.l. in the south-west, as this vegetation type gradually changes to Stipagrostio uniplumis-Acacietum melliferae.

\subsection{Combreto collini-Terminalietum sericeae grewietosum flavae subass. nov.}

The type for this subassociation is relevé 1439, sampled on 29 April 2004 at $20^{\circ} 05^{\prime} 05^{\prime \prime}$ S, $20^{\circ} 29^{\prime} 08^{\prime \prime}$ E. Forty-five relevés were classified into this subassociation, which is characterised by the diagnostic species Grewia flava, Clerodendrum ternatum, Rhigozum brevispinosum, Neorautanenia amboensis, Ipomoea bolusiana, Talinum crispatulum, Indigofera bainesii, Eragrostis rigidior, Tylosema esculentum, Anthephora pubescens and Boscia albitrunca. These are constantly associated with Urochloa brachyura, Stipagrostis uniplumis var. uniplumis, Vernonia poskeana, Terminalia sericea, Melinis repens subsp. grandiflora, Oxygonum alatum, Phylenoptera nelsii, Bulbostylis hispidula, Acanthosicyos naudinianus, Xenostegia tridentata subsp. angustifolia, Tephrosia burchellii, Dichrostachys cinerea, Commiphora angolensis, Grewia flavescens, Acrotome spp., Schmidtia pappophoroides, Megaloprotachne albescens, Limeum fenestratum, Acacia fleckii and Merremia verecunda. A total of 135 species were observed here, with, on average, 41 species per $1000 \mathrm{~m}^{2}$.

Tree cover is virtually absent, making this subassociation a high, moderately closed shrubland (Figure $3 \mathrm{~m}$ and
Figure 4o). It occurs on sand drift plains and occasionally in sandy omiramba at an altitude of between 1040 m.a.s.l. and 1450 m.a.s.l. The sands are generally deep to very deep. The most common disturbances observed are bush encroachment and sometimes severe overgrazing.

Next to Dichapetalum cymosum, Elephantorrhiza elephantina also occurs occasionally. Although this suffrutex is less poisonous to cattle, it is still a threat to grazers. Grass cover in this variation is in general low. The annual species Megaloprotachne albescens, Urochloa brachyura and Melinis repens subsp. grandiflora dominate the grass sward. Important perennial species are Stipagrostis uniplumis var. uniplumis, Eragrostis rigidior, Eragrostis lehmanniana and Eragrostis trichophora. In general, the grazing is regarded as poor to mediocre.

\subsection{Combreto collini-Terminalietum sericeae typicum subass. nov.}

The type for this subassociation is relevé 1288, sampled on 25 April 2004 at $19^{\circ} 48^{\prime} 14^{\prime \prime}$ S, 18 $8^{\circ} 35^{\prime} 45^{\prime \prime}$ E. Sixty-one relevés were classified into this subassociation, which is characterised by the constant occurrence of Terminalia sericea, Combretum collinum, Grewia flavescens, Tephrosia burchellii, Stipagrostis uniplumis var. uniplumis, Melinis repens subsp. grandiflora, Xenostegia tridentata subsp. angustifolia, Commiphora angolensis, Bauhinia petersiana subsp. macrantha, Megaloprotachne albescens, Bulbostylis hispidula, Acrotome species, Vernonia poskeana, Phyllanthus pentandrus, Phylenoptera nelsii, Gisekia africana, Digitaria seriata, Ochna pulchra, Urochloa brachyura, Acacia ataxacantha, Hibiscus meeusei, Tephrosia lupinifolia, Dichrostachys cinerea and Ipomoea hackeliana. A total of 98 species were observed here, with, on average, 37 species per $1000 \mathrm{~m}^{2}$.

Combreto collini-Terminalietum sericeae typicum only occasionally has trees, making it a short, moderately closed bushland with a strong shrubland character, dominated by Terminalia sericea and various Combretum species - of which Combretum collinum is the most prominent (Figure $3 \mathrm{n}$ and Figure $4 \mathrm{p}$ ). The sandy habitat occurs on extensive plains ranging between 1020 m.a.s.l. and 1500 m.a.s.l. altitude.

The grazing is dominated by the annual Megaloprotachne albescens, followed by Aristida stipitata. Common perennial grass species are Stipagrostis uniplumis var. uniplumis and Eragrostis lehmanniana. The grazing is thus relatively poor, especially in the dry season, and cattle have to rely on browse for fodder.

\subsection{Combreto collini-Terminalietum sericeae burkeaetosum africanae subass. nov.}

The type for this subassociation is relevé 1411, sampled on 27 April 2004 at $19^{\circ} 54^{\prime} 48^{\prime \prime}$ S, 1903'59” E. Forty-seven relevés were classified into this subassociation, which is characterised by the constant occurrence of Terminalia sericea, Ochna pulchra, Combretum collinum, Bauhinia petersiana subsp. macrantha, Lonchocarpus nelsii, Stipagrostis uniplumis var. uniplumis, Megaloprotachne albescens, Digitaria seriata, 
Xenostegia tridentata subsp. angustifolia, Combretum psidioides, Burkea africana, Eragrostis pallens, Grewia flavescens, Phyllanthus pentandrus, Gisekia africana, Tephrosia burchellii, Vernonia poskeana, Melinis repens subsp. grandiflora and Bulbostylis hispidula. A total of 72 species were observed here, with, on average, 31 species per $1000 \mathrm{~m}^{2}$.

Characteristic of this subassociation are Burkea africana trees amidst a shrubland dominated by Terminalia sericea and various Combretum species. The structure is thus a typically short, moderately closed bushland (Figure 3o and Figure 4q), found mostly on sandy plains, occasionally also on dunes, between 1030 m.a.s.l. and 1460 m.a.s.l. altitude. Grazing conditions approximate those found in Combreto colliniTerminalietum sericeae typicum.

\section{Terminalio sericeae-Schinziophytetum rautanenii ass. nov.}

The type for this association is relevé 4013, sampled on 26 March 1992 at $19^{\circ} 25^{\prime} 17^{\prime \prime}$ S, 18 $8^{\circ} 23^{\prime} 20^{\prime \prime}$ E. Six relevés were classified into this association, which is characterised by the diagnostic species Strychnos pungens, Schinziophyton rautanenii, Erlangea misera, Phyllanthus maderaspatensis, Bidens spp., Croton gratissimus, Tricholaena monachne, Thunbergia aurea, Rhynchosia venulosa, Monechma debile, Hypoestes forskaolii, Rhynchosia sublobata, Ximenia americana, Hibiscus vitifolius and Vangueria infausta. These are constantly associated with Terminalia sericea, Stipagrostis uniplumis var. uniplumis, Ochna pulchra, Combretum collinum, Grewia flavescens, Burkea africana, Bauhinia petersiana subsp. macrantha, Aristida stipitata and Melinis repens subsp. grandiflora. A total of 70 species were observed here, with, on average, 34 species per $1000 \mathrm{~m}^{2}$.

Terminalio sericeae-Schinziophytetum rautanenii has been found on the crests and upper slopes of the high longitudinal dunes just north of the Rooiboklaagte omuramba (2100' S). Additional Schinziophyton rautanenii (Manketti tree) groves could be identified from a distance at a few locations in the Gam and Eiseb area. The dunes on which the Manketti groves occur vary in altitude between 1240 m.a.s.l. in the south and only 1110 m.a.s.l. further north. Long-term average annual rainfall ranges between $400 \mathrm{~mm}$ and $500 \mathrm{~mm}$. The deep sands found here $(>150 \mathrm{~cm})$ show only few signs of wind erosion and weak surface crusting, with almost no disturbances. The tall Manketti trees associated with a dense understorey shrub layer result in a tall, moderately closed thicket (Figure $3 p$ and Figure $4 r$ ).

\section{Burkeo africanae-Pterocarpetum angolensis ass. nov.}

The type for this association is relevé 1312, sampled on 27 April 2004 at $19^{\circ} 50^{\prime} 54^{\prime \prime}$ S, 18 $8^{\circ} 57^{\prime} 08^{\prime \prime}$ E. Sixteen relevés were classified within this association, which is characterised by the diagnostic species Pterocarpus angolensis, Burkea africana, Crotalaria flavicarinata, Hermannia eenii and Rotheca myricoides. These are constantly associated with Terminalia sericea, Bauhinia petersiana subsp. macrantha, Ochna pulchra,
Combretum collinum, Digitaria seriata, Phylenoptera nelsii, Combretum psidioides, Stipagrostis uniplumis var. uniplumis, Megaloprotachne albescens, Gisekia africana, Xenostegia tridentata subsp. angustifolia, Panicum kalaharense, Aristida stipitata, Vernonia poskeana, Tephrosia lupinifolia, Melinis repens subsp. repens, Eragrostis pallens, Commelina africana var. krebsiana and Bulbostylis hispidula. A total of 61 species were observed here, with, on average, 32 species per $1000 \mathrm{~m}^{2}$.

This association occurs mostly in the northern sandy plains of the Otjituuo and Gam Conservancies. Patches of this vegetation type can also be found in the northern Okamatapati and Otjinene Conservancies. It is fairly widespread further north and has been described as 'Burkea africana tall closed woodland' by Hines (1992). Typically, the habitat consists of extensive sandy plains ranging at altitudes of between 1050 m.a.s.l. and 1340 m.a.s.l. The depth of the sands is generally more than $150 \mathrm{~cm}$, with weak or no surface crusting and signs of only slight wind erosion. Typical disturbance factors in these bushlands are frequent fires and bush encroachment.

Although Pterocarpus angolensis (teak tree) is a very prominent species, reaching a height of $12 \mathrm{~m}-15 \mathrm{~m}$, neither its density nor its trunk diameter warrants commercial exploitation of this timber resource. Few of the other woody species reach tree height, the only ones being Burkea africana and, occasionally, Terminalia sericea and Combretum collinum. Owing to the relatively high cover of understorey shrubs, the structure is typically a tall, moderately closed thicket (Figure $3 q$ and Figure 4s).

\section{Discussion}

\section{Higher syntaxonomic groupings and relations to similar vegetation in southern Africa}

The initial splitting of the dataset between the sandveld and the hardeveld - that is, between the deep sands of the central Kalahari basin and the surrounding transitions to the Central Plateau (De Pauw et al. 1998), with more mesic conditions on shallower soils and/or soils with higher loam content - is reflected as between mostly the broad-leaved savannas (associations 12-14) and the microphyll savannas (associations 1-11).

The broad-leafed savannas in turn can be split into two major groupings: Strohbach and Petersen (2007) suggest the recognition of a vegetation class Burkeo-Pterocarpetea, which is considered representative of the ZambesianBaikiaea Woodlands ecoregion of the World Wildlife Fund (WWF) (Vetter 2001). This class is typically a semi-open woodland characterised by, '... various Caesalpinioideae (Burkea africana, Bauhinia petersiana, occasionally Baikiaea plurijuga and Guibourtia coleosperma) and Papilionoideae (Pterocarpus angolensis), as well as Combretaceae (Combretum spp., Terminalia sericea)' (Vetter 2001:n.p). This applies, to a large extent, to both the Terminalio sericeae-Schinziophytetum rautanenii and the Burkeo africanae-Pterocarpetum angolensis, although both are relatively species-poor in terms of the 


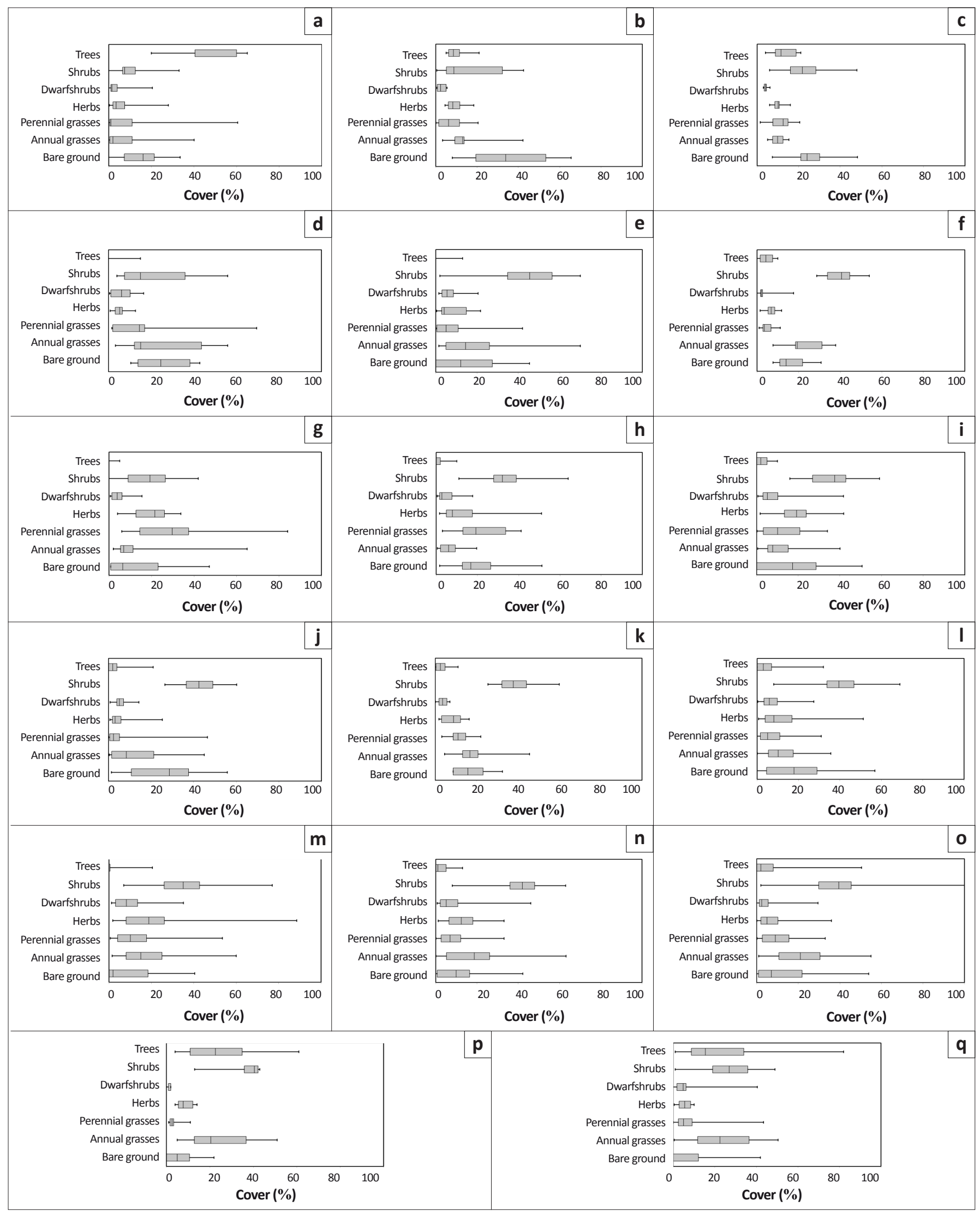

Source: Author's own creation

FIGURE 3: Box-and-whisker plots of the typical structure of the various associations and subassociations, (a) Acacio fleckii-Terminalietum prunioidis, (b) Acacio tortilis-Combretetum imberbis, (c) Ptycholobio biflori-Acacietum luederitzii, (d) Eragrostio echinocloideae-Eriocephaloetum luederitziani, (e) Acacio melliferae-Catophractetum alexandri, (f) Acacio melliferae-Hyphaenetum petersianae, (g) Eragrostio rigidioris-Urochloaetum brachyurae, (h) Tarchonantho camphorate-Acacietum eriolobae, (i) Stipagrostio uniplumis-Acacietum melliferae rhigozetosum brevispinosi, (j) Stipagrostio uniplumis-Acacietum melliferae typicum, (k) Terminalio sericeae-Acacietum eriolobae, (I) Combreto collini-Terminalietum sericeae acacietosum melliferae, (m) Combreto collini-Terminalietum sericeae grewietosum flavae, (n) Combreto collini-Terminalietum sericeae typicum, (o) Combreto collini-Terminalietum sericeae burkeaetosum africanae, (p) Terminalio sericeae-Schinziophytetum rautanenii and (q) Burkeo africanae-Pterocarpetum angolensis. 

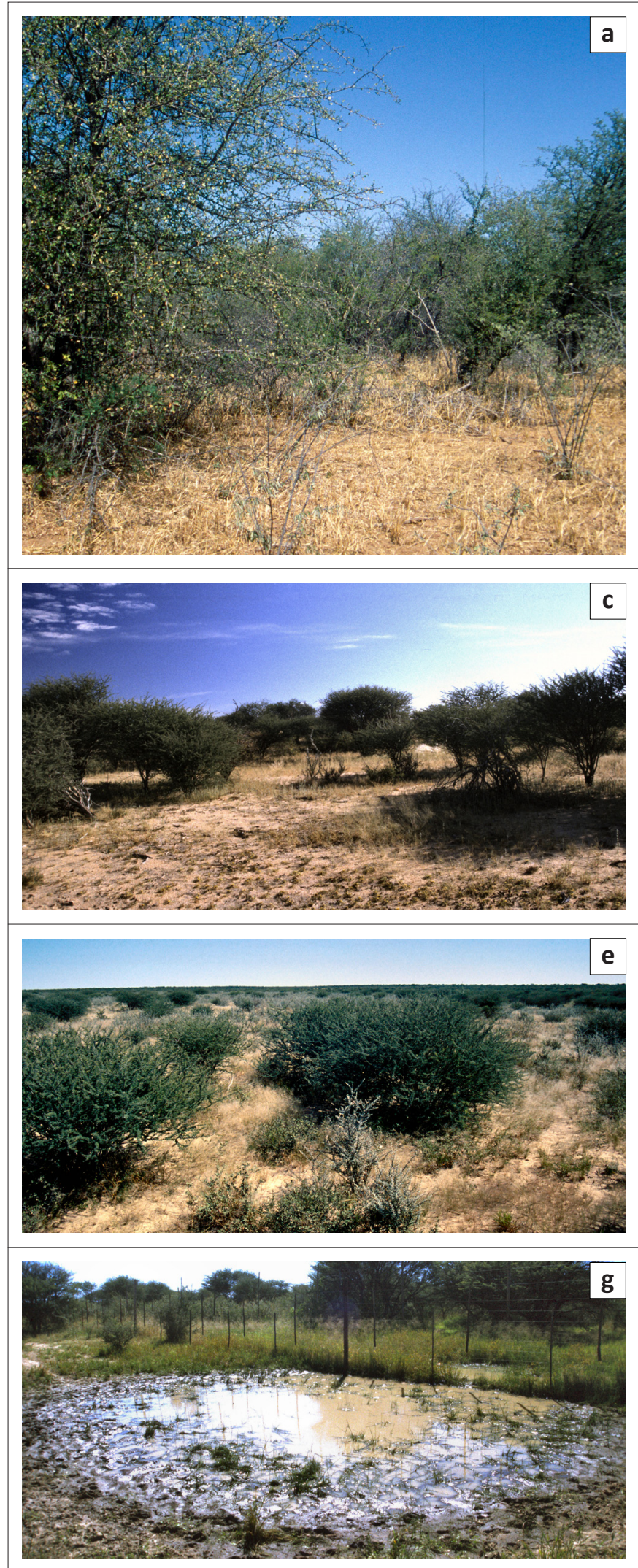

\section{Source: Figures 4a, 4e and 4i-4s photographed by Marianne Strohbach. Figures 4b-4h photographed by the author}

FIGURE 4: Typical examples of various associations and subassociations, (a) Acacio fleckii-Terminalietum prunioidis, (b) Acacio tortilis-Combretetum imberbis, (c) Ptycholobio biflori-Acacietum luederitzii, (d) Eragrostio echinocloideae-Eriocephaloetum luederitziani, (e) Acacio melliferae-Catophractetum alexandri, (f) Acacio melliferae-Hyphaenetum petersianae, (g) Panicum gilvum-Marsilea vlei, (h) Eragrostio rigidioris-Urochloaetum brachyurae, (i) Tarchonantho camphorate-Acacietum eriolobae, (j) Stipagrostio uniplumis-Acacietum melliferae rhigozetosum brevispinosi, (k) Stipagrostio uniplumis-Acacietum melliferae typicum, (I) Terminalio sericeae-Acacietum eriolobae, (m) degraded Combreto collini-Terminalietum sericeae acacietosum melliferae, (n) Combreto collini-Terminalietum sericeae acacietosum melliferae in better condition, (o) Combreto collini-Terminalietum sericeae grewietosum flavae, (p) Combreto collini-Terminalietum sericeae typicum, (q) Combreto collini-Terminalietum sericeae burkeaetosum africanae, (r) Terminalio sericeae-Schinziophytetum rautanenii and (s) Burkeo africanae-Pterocarpetum angolensis. 

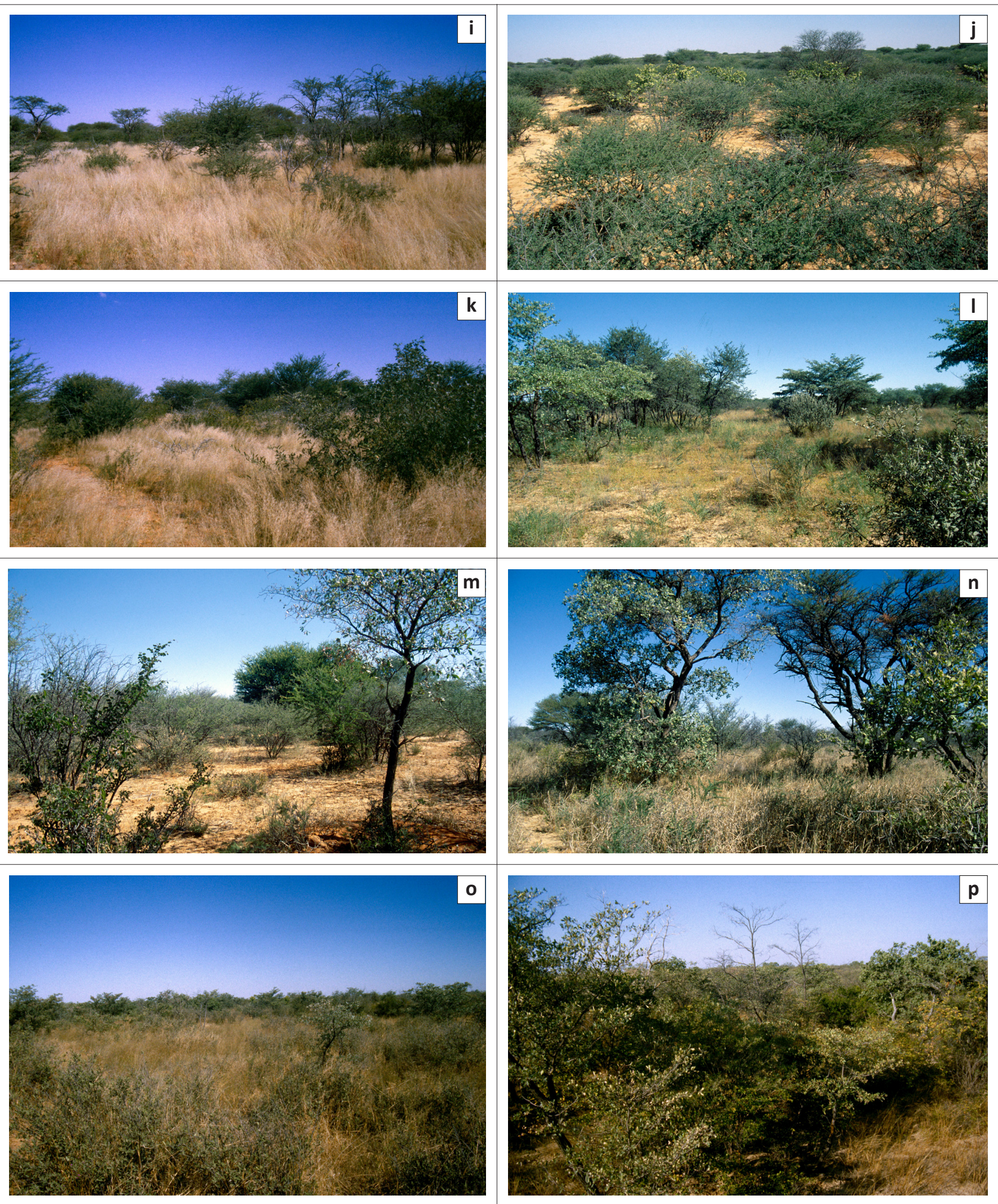

Source: Figures 4a, 4e and 4i-4s photographed by Marianne Strohbach. Figures 4b-4h photographed by the author

FIGURE 4 (Continues...): Typical examples of various associations and subassociations, (a) Acacio fleckii-Terminalietum prunioidis, (b) Acacio tortilis-Combretetum imberbis, (c) Ptycholobio biflori-Acacietum luederitzii, (d) Eragrostio echinocloideae-Eriocephaloetum luederitziani, (e) Acacio melliferae-Catophractetum alexandri, (f) Acacio melliferae-Hyphaenetum petersianae, (g) Panicum gilvum-Marsilea vlei, (h) Eragrostio rigidioris-Urochloaetum brachyurae, (i) Tarchonantho camphorateAcacietum eriolobae, (j) Stipagrostio uniplumis-Acacietum melliferae rhigozetosum brevispinosi, (k) Stipagrostio uniplumis-Acacietum melliferae typicum, (I) Terminalio sericeae-Acacietum eriolobae, $(\mathrm{m})$ degraded Combreto collini-Terminalietum sericeae acacietosum melliferae, $(\mathrm{n})$ Combreto collini-Terminalietum sericeae acacietosum melliferae in better condition, (o) Combreto collini-Terminalietum sericeae grewietosum flavae, (p) Combreto collini-Terminalietum sericeae typicum, (q) Combreto collini-Terminalietum sericeae burkeaetosum africanae, (r) Terminalio sericeae-Schinziophytetum rautanenii and (s) Burkeo africanae-Pterocarpetum angolensis. 

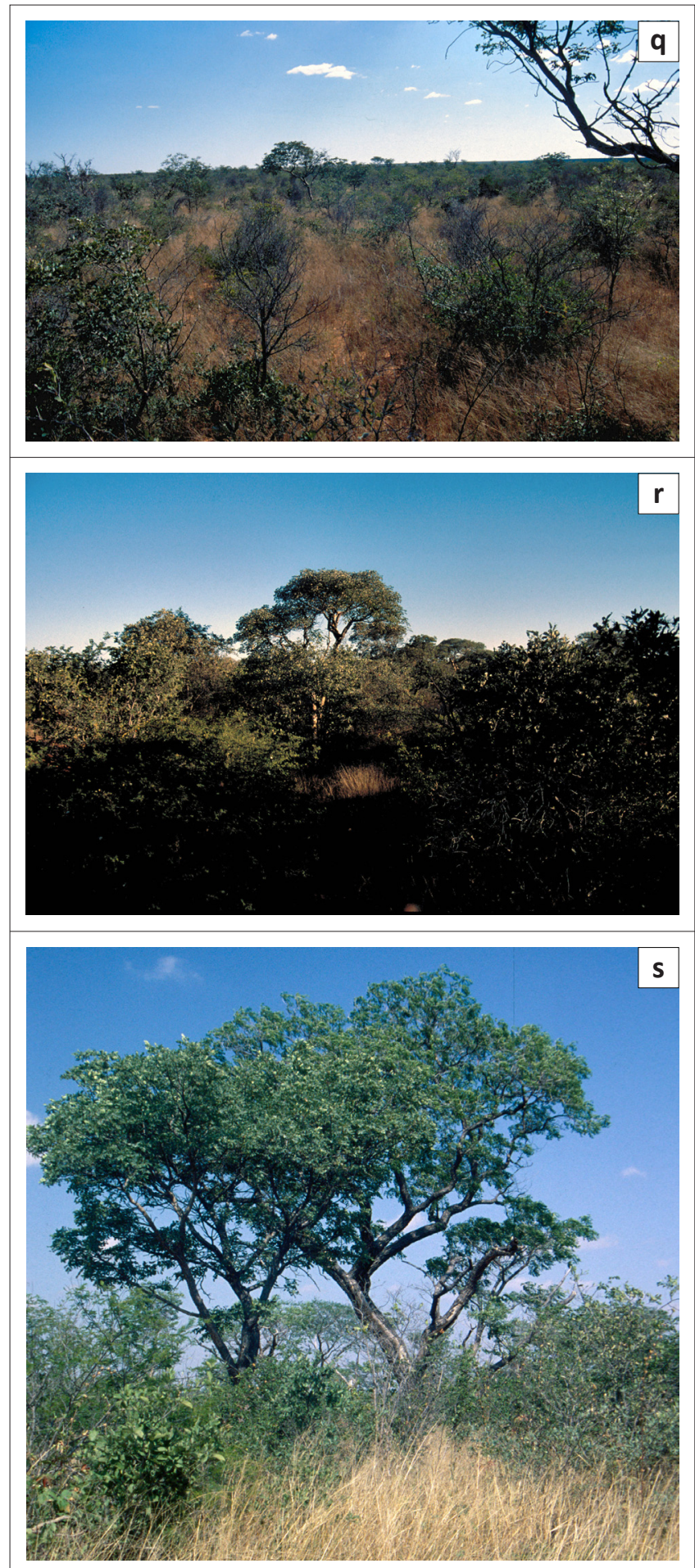

Source: Figures $4 \mathrm{a}, 4 \mathrm{e}$ and $4 \mathrm{i}-4 \mathrm{~s}$ photographed by Marianne Strohbach. Figures $4 \mathrm{~b}-4 \mathrm{~h}$ photographed by the author

FIGURE 4 (Continues...): Typical examples of various associations and subassociations, (a) Acacio fleckii-Terminalietum prunioidis, (b) Acacio tortilisCombretetum imberbis, (c) Ptycholobio biflori-Acacietum luederitzii, (d) Eragrostio echinocloideae-Eriocephaloetum luederitziani, (e) Acacio melliferaeCatophractetum alexandri, (f) Acacio melliferae-Hyphaenetum petersianae, (g) Panicum gilvum-Marsilea vlei, (h) Eragrostio rigidioris-Urochloaetum brachyurae, (i) Tarchonantho camphorate-Acacietum eriolobae, (j) Stipagrostio uniplumis-Acacietum melliferae rhigozetosum brevispinosi, (k) Stipagrostio uniplumis-Acacietum melliferae typicum, (I) Terminalio sericeae-Acacietum eriolobae, $(\mathrm{m})$ degraded Combreto collini-Terminalietum sericeae acacietosum melliferae, (n) Combreto collini-Terminalietum sericeae acacietosum melliferae in better condition, (o) Combreto collini-Terminalietum sericeae grewietosum flavae, (p) Combreto collini-Terminalietum sericeae typicum, (q) Combreto collini-Terminalietum sericeae burkeaetosum africanae, (r) Terminalio sericeaeSchinziophytetum rautanenii and (s) Burkeo africanae-Pterocarpetum angolensis.
Caesalpinioideae, compared to the communities described for the central Kavango (Strohbach \& Petersen 2007). These two associations thus form the southernmost, most xeric extent of Burkeo-Pterocarpetea and the Zambesian-Baikiaea Woodlands ecoregion of the WWF (Vetter 2001), extending into north-western Botswana. Bekker and De Wit (1991) make no mention of such species combinations in their vegetation description, though.

In contrast, the Combreto collini-Terminalietum sericeae has no woodland character and generally forms a shrubland, at best a bushland. The Caesalpinioidae are represented only by Bauhinia petersiana subsp. macrantha (a shrub) and occasionally Burkea africana (as a short tree). Owing to, especially, these structural, but also to compositional differences, this association is to be recognised as a separate higher syntaxon, possibly a class Combreto-Terminalietea sericeae. The fact that the subdivisions of Combreto colliniTerminalietum sericeae are recognised only as subassociations is because of the very close compositional relationship between them and this needs to be confirmed through further studies. This association covers most of the landscape of the eastern communal areas and is expected to make a significant contribution to the landscape of the Kalahari Acacia-Baikiaea woodlands as defined by the WWF (Spriggs 2001a). Bekker and De Wit (1991) mention such vegetation occurs west of the Ghanzi Ridge, whilst Cole and Brown (1976) describe such vegetation for the Kalahari Sand Plain south and west of the Ghanzi Ridge. Similar vegetation has also been found elsewhere in Namibia, in particular in the Maroelaboom area (e.g. at the Sonop observatory - Jürgens et al. 2010) and in north-central Namibia (Kangombe 2010). This vegetation type seems to have resemblances to the Central Sandy Bushveld (SVcb 12) of South Africa (Mucina \& Rutherford 2006). The Central Sandy Bushveld includes the Nylsvley study area, which was subject to extensive ecosystem research (Scholes \& Walker 1993).

The subdivision of the hardeveld is not as clear-cut. It is speculated that the Acacio fleckii-Terminalietum prunioidis and the Acacio melliferae-Hyphaenetum petersianae could potentially form a separate class. This is also suggested by Giess (1998), who recognised the Karsteveld as separate from the Thornbush savanna. Similar vegetation, especially to Acacio fleckii-Terminalietum prunioidis, has been described by Cole and Brown (1976) for the Ghanzi Ridge area north-east of Ghanzi towards the Ngamiland border.

The Eragrostis echinocloideae-Eriocephaloetum luederitziani and the Acacio melliferae-Catophractetum alexandri form typical niche vegetation related to shallow carbonate-rich soils. There are obvious resemblances between these two associations, warranting their own higher syntaxonomic unit. Acacio melliferae-Catophractetum alexandri, especially, occurs widespread throughout eastern and north-eastern Namibia (Hines 1992; Leser 1972), but also in north-western Botswana (Cole \& Brown 1976). It could not be established whether similar vegetation exists within the Kalahari Bushveld types of South Africa (Mucina \& Rutherford 2006). 
TABLE 1: Association names as used in the present study, as related to the community names used in the original 2004 study and the 2009 vegetation mapping units.

\begin{tabular}{|c|c|c|}
\hline Association & Original name in Strohbach et al. (2004) & Included in mapping unit in Hüttich et al. (2009) \\
\hline Acacio fleckii-Terminalietum prunioides & Terminalia prunioides-Acacia fleckii thickets & Terminalia prunioides thickets \\
\hline Acacio tortilis-Combretetum imberbis & Combretum imberbe-Acacia tortilis woodlands & Combretum imberbe-Acacia tortilis woodlands \\
\hline Ptychtolobio biflori-Acacietum luederitzii & Acacia luederitzii-Ptychtolobium biflorum bushlands & $\begin{array}{l}\text { Acacia luederitzii-Ptichtolobium biflorum Omatako } \\
\text { floodplains }\end{array}$ \\
\hline $\begin{array}{l}\text { Eragrostis echinocloideae-Eriocephaloetum } \\
\text { luederitziani }\end{array}$ & $\begin{array}{l}\text { Eriocephalus luederitzianus-Eragrostis echinocloidea } \\
\text { shrublands, as well as Enneapogon desvauxii-Acacia } \\
\text { hebeclada shrublands }\end{array}$ & $\begin{array}{l}\text { Enneapogon desvauxii-Eriocephalus luederitzianus short } \\
\text { shrublands }\end{array}$ \\
\hline Acacio melliferae-Catophractetum alexandri & Acacia mellifera-Catophractes alexandri shrublands & $\begin{array}{l}\text { Included in the Acacia mellifera-Stipagrostis uniplumis } \\
\text { shrublands }\end{array}$ \\
\hline Acacio melliferae-Hyphaenetum petersianae & Hyphaene petersiana bushlands & Hyphaene petersiana plains \\
\hline Panicum gilvum-Marsilea vlei community & Panicum gilvum-Marsilea grasslands & Not mapped \\
\hline Eragrosto rigidioris-Urochloaetum brachyurae & Eragrostis rigidior-Urochloa brachyuran shrublands & Eragrostis rigidior-Urochloa brachyura grasslands \\
\hline Tarchonantho camphorate-Acacietum eriolobae & Newly defined, not recognised by Strohbach et al. (2004) & Included in Acacia erioloba-Terminalia sericea bushlands \\
\hline Stipagrostio uniplumis-Acacietum melliferae & Acacia mellifera-Stipagrostis uniplumis shrublands (pro parte) & Acacia mellifera-Stipagrostis uniplumis shrublands \\
\hline Terminalio sericeae-Acacietum eriolobae & Terminalia sericea-Acacia erioloba bushlands & Acacia erioloba-Terminalia sericea bushlands \\
\hline Combreto collini-Teminalietum sericeae & $\begin{array}{l}\text { Terminalia sericea-Combretum collinum shrublands and } \\
\text { bushlands (pro parte) }\end{array}$ & $\begin{array}{l}\text { Terminalia sericea-Combretum collinum shrublands and } \\
\text { bushlands }\end{array}$ \\
\hline Terminalio sericeae-Schinziophytetum rautanenii & Terminalia sericea-Schinziophyton rautanenii bushlands & $\begin{array}{l}\text { Included in the Pterocarpus angolensis-Burkea africana } \\
\text { woodlands }\end{array}$ \\
\hline Burkeo africanae-Pterocarpetum angolensis & Pterocarpus angolensis-Burkea africana bushlands & Pterocarpus angolensis-Burkea africana woodlands \\
\hline
\end{tabular}

For more information, please see the full reference list of the article: Strohbach, B.J., 2014, 'Vegetation of the eastern communal conservancies in Namibia: I. Phytosociological descriptions', Koedoe 56(1), Art. \#1116, 18 pages. http://dx.doi.org/10.4102/koedoe.v56i1.1116

The remainder of the microphyll savannas are typical for the Acacietea (Volk \& Leippert 1971); that is, they are dominated by various species of the genus Acacia. The Acacietea are divided by both Giess (1998) and the WWF into two larger units, these being the Thornbush savanna (roughly equivalent to the Namibian savanna woodlands Spriggs 2001b) and the Camelthorn savanna, which forms the northern part of the Kalahari xeric savanna (Seymour 2001). Typical Camelthorn savanna elements are the Terminalio sericeae-Acacietum eriolobae and the Tarchonantho camphorateAcacietum eriolobae. Whereas the former association seems to occur widespread in western Botswana (Cole \& Brown 1976) and has been described also from the Sandveld Research Station north of Gobabis in Namibia (Jürgens et al. 2010; September 2006), Tarchonantho camphorate-Acacietum eriolobae has resemblances to the Kimberley Thornveld (SVk 4) or Kuruman Thornveld (SVk 9) of South Africa (Mucina \& Rutherford 2006).

\section{Vegetation mapping}

The initial vegetation map prepared by Strohbach et al. (2004) was refined by Hüttich et al. (2009) and is presented in that publication. For the mapping of the vegetation types, a number of associations had to be combined, in a similar way as was undertaken for the SOTER methodology (FAO 1995) or the landscapes of the Kalahari Gemsbok National Park (Van Rooyen et al. 2008). For purposes of comparison, the mapping units described by Hüttich et al. (2009) are related to the vegetation associations described in Table 1 in this article.

\section{Land use and land degradation}

Large parts of the vegetation have been found to be either over-utilised, subject to regular heavy fires, or bush encroached. In general, bush encroachment in these areas is regarded as high (De Klerk 2004), thus further threatening the grazing resources. With this in mind, many farmers resort to the harvesting of droppers (fence posts) from Terminalia sericea as an extra source of income. Overgrazing, especially if combined with overutilisation of this woody resource and / or frequent fires in the area, will lead to an increased exposure of the soil surface to both wind erosion and denitrification, the latter as a result of increased heating of the surface during the day (Schlesinger \& Peterjohn 1991; Schlesinger et al. 1996). The Kalahari sands are, in any case, extremely nutrient-poor (Dougill \& Thomas 2004; Wang et al. 2007) such a denitrification cycle will lead to further reduction in the soil nutrient status and thus to further reduction in the vegetation cover. This is a classic example of 'biological feedback' into desertification (Schlesinger et al. 1990), in an ecosystem which is, in any case, predicted to aridify and turn into a mobile sand sea over the next half century as a result of global climate change (Midgley et al. 2005; Thomas, Knight \& Wiggs 2005). This will mean an even more rapid resource loss over the entire area, resulting in major socioeconomic problems for the country. To ensure sustainable land use in the area, it is essential that good vegetative cover be maintained, whether dominated by grass, shrub or tree.

\section{Conclusion}

The vegetation within the eastern communal conservancies of Namibia forms a large expanse of transitional vegetation between the xeric southern Kalahari and the woodlands of the northern Kalahari, with adjacent transitions to the Central Plateau with its stonier and/or loamier soils. As the soils are generally nutrient-poor (Dougill \& Thomas 2004; Wang et al. 2007), the entire ecosystem is extremely fragile and susceptible to desertification (Thomas et al. 2005). In order to prevent this, proper land-use planning is essential for the emerging and established communal conservancies. This article provides important baseline information needed for proper integrated land-use planning, also in line with the National Land Reform Programme of the Government of Namibia (Haub 2009). 
This article also provides an important contribution towards the inventorying of vegetation in Namibia under the vegetation survey of Namibia project (Strohbach 2001; Strohbach \& Jürgens 2010). The newly described vegetation associations represent four important ecoregions in Namibia, being the Forest Savannas and Woodlands, the Karstveld, the Thornbush Savanna and the Camelthorn savannah sensu Giess (1998). The higher order syntaxonomy of these associations is still unclear, mainly because only limited similar studies exist within Namibia. This makes an assignment to a specific syntaxonomic rank impossible.

Future studies should concentrate on the description of adjacent areas especially within the Karstveld, Thornbush and Camelthorn savannas, to confirm and expand the classification results of the hardeveld. As more such studies become available, a better understanding of the higher order syntaxa will become available. A phytosociological study to the seasonal wetlands of the Kalahari, building on pioneer work by Hines (1993), will assist to deepen the understanding of these azonal features, which also form a major habitat in this ecoregion.

There is an urgent need for an online register of vegetation associations for southern Africa, as has been suggested by Brown et al. (2013). This will facilitate the proper description and comparison of vegetation types in relation to similar types and ecozones in southern Africa.

\section{Acknowledgements}

Thanks are due to Ms Marianne Strohbach for her help with the fieldwork. The assistance of the staff of the National Herbarium of Namibia in the identification of plant specimens is also gratefully acknowledged. This project was co-funded by the Global Environment Facility through the Desert Margins Programme and the Government of Namibia, through the recurrent budget of the Directorate Agriculture Research and Training.

\section{Competing interests}

The author declares that he has no financial or personal relationships which may inappropriately have influenced him in writing this article.

\section{References}

Bekker, R.P. \& De Wit, P.V., 1991, 'Contribution to the vegetation classification of Botswana, Field document 34', Food and Agriculture Organization of the United Nations, United Nations Development Programme and Government of Botswana, Gaborone.

Bester, F.V., 1988, 'Die bepaling van die grasproduksie van natuurlike veld [The determination of grass production off natural veld]', Agricola 6, 26-30.

Bester, F.V., 1989, 'Navorsing gedoen met betrekking tot gifblaar Dichapetalum cymosum [Research done in regards of gifblaar Dichapetalum cymosum]', Agricola 7, 60-64.

Bester, F.V. \& Reed, E.R., 2003, 'Grass yield in the Sandveld Camel Thorn Savanna: Rainfall vs stocking rate', Spotlight on Agriculture 71, Ministry of Agriculture, Water and Rural Devlopment, Windhoek.

Bester, F.V., Van Eck, J.A.J., Kolling, H. \& Van Rooyen, B., 2003a, 'The influence of stocking rate on the grass yield in the Camel Thorn Savanna', Spotlight on Agriculture 70, Ministry of Agriculture, Water and Rural Devlopment, Windhoek.

Bester, F.V., Van Eck, J.A.J., Kolling, H. \& Van Rooyen, B., 2003b, 'Grazing capacity in the Sandveld Camel Thorn Savanna of Namibia', Spotlight on Agriculture 72, Ministry of Agriculture, Water and Rural Devlopment, Windhoek.
Bester, F.V., Van Eck, J.A.J., Kolling, H. \& Van Rooyen, B., 2003c, 'The influence of stocking rate on the distribution of individual grass species in the sward', Spotlight on Agriculture 74, Ministry of Agriculture, Water and Rural Devlopment, Windhoek.

Botha, L., 1998, 'History of drought in Namibia', Agricola 10, 5-12.

Brown, L.R., Du Preez, P.J., Bezuidenhout, H., Bredenkamp, G.J., Mostert, T.H., Collins, N.B. et al., 2013, 'Guidelines for phytosociological classifications and description of vegetation in southern Africa', Koedoe 55, 1103. http://dx.doi.org/10.4102/ koedoe.v55i1.1103

Bruelheide, H., 1997, 'Using formal logic to classify vegetation', Folia Geobotanica Phytotaxonomia 32, 41-46. http://dx.doi.org/10.1007/BF02803883

Bruelheide, H. \& Flintrop, T., 1994, 'Arranging phytosociological tables by speciesrelevé groups', Journal of Vegetation Science 5, 311-316. http://dx.doi. org/10.2307/3235854

Burke, A. \& Strohbach, B.J., 2000, 'Review: Vegetation studies in Namibia', Dinteria 26, 1-24.

Chytrý, M., Tichý, L., Holt, J. \& Botta-Dukat, Z., 2002, 'Determination of diagnostic species with statistic fidelity measures', Journal of Vegetation Science 13, 79-90. http://dx.doi.org/10.1111/j.1654-1103.2002.tb02025.x

Cole, M.M. \& Brown, R.C., 1976, 'The vegetation of the Ghanzi area of western Botswana', Journal of Biogeography 3, 169-196. http://dx.doi. org/10.2307/3038009

De Klerk, J.N., 2004, 'Bush encroachment in Namibia. Report on Phase 1 of the bush encroachment research, monitoring and management project', Ministry of Environment and Tourism, Windhoek.

De Pauw, E., Coetzee, M.E., Calitz, A.J., Beukes, H. \& Vits, C., 1998, 'Production of an agro-ecological zones map of Namibia (first approximation). Part II: Results', Agricola 10, 33-43.

De Sousa Correia, R.J. \& Van Rensburg, L., 2000, 'Geographical distribution and local occurence of Dichapetalum cymosum (Hook) Engl. (gifblaar) in Namibia and surrounding areas', Agricola 11, 19-28.

Department Landbou Tegniese Dienste, 1979, 'Die afbakening van redelike homogene boerderygebiede van die noordelike en sentrale substreke van S.W.A. met die heersende knelpunte en beoogde ontwikkleingsprogramme vir die verskillende bedryfstakke [The delimitation of relative homogenous farming areas in the northern and central subregions of SWA with their constraints and planned development programmes for the different branches]', Department Landbou Tegniese Dienste, Windhoek.

Dengler, J., Jansen, F., Glöckler, F., Peet, R.K., De Cáceres, M., Chytrý, M. et al., 2011, 'The global index of vegetation-plot databases (GIVD): A new resource for vegetation science', Journal of Vegetation Science 22, 582-597. http://dx.doi. org/10.1111/j.1654-1103.2011.01265.x

Dougill, A.J. \& Thomas, D.S.G., 2004, 'Kalahari sand soils: Spatial heterogeneity, biological soil crusts and land degradation', Land Degradation \& Development 15 233-244. http://dx.doi.org/10.1002/ldr.611

Edwards, D., 1983, 'A broad-scale structural classification of vegetation for practical purposes', Bothalia 14, 705-712.

Espach, C., Lubbe, L.G. \& Ganzin, N., 2006, 'Determining grazing capacity in Namibia: Approaches and methodologies', Agricola 16, 28-39.

Espach, C., Lubbe, L.G. \& Ganzin, N., 2010, 'Determining grazing capacity in Namibia with the aid of remote sensing', Agricola 20, 41-61.

Food and Agricultural Organization (FAO), 1995, 'Global and national soils and terrain digital databases (SOTER)', World soil resources reports 74, Rev. 1, Land and Water Development Division, Food and Agriculture Organization of the United Nations, Rome.

Geological Survey, 1980, South West Africa/Namibia geological map 1:1000000, Geological Survey of the Republic of South Africa and South West Africa/Namibia, Windhoek.

Giess, W., 1998, 'A preliminary vegetation map of Namibia', Dinteria 4, 1-112.

Haub, O., 2009, 'Understanding of land-use planning and its relevance in Namibia', Namibia Land Management ser. 1, Namibia Institute for Democracy and Ministry of Lands and Resettlement, Windhoek.

Hennekens, S.M. \& Schaminée, J.H.J., 2001, 'TURBOVEG, a comprehensive data base management system for vegetation data', Journal of Vegetation Science 12, 589591. http://dx.doi.org/10.2307/3237010

Hines, C.J.H., 1992, 'An ecological study of the vegetation of eastern Bushmanland (Namibia) and its implications for development', MSc thesis, Institute of Natura Resources, University of Natal, Pietermaritzburg.

Hines, C.J.H., 1993, 'Temporary wetlands of Bushmanland and Kavango; northeast Namibia', Madoqua 18, 57-69.

Hüttich, C., Gessner, U., Herold, M., Strohbach, B.J., Schmidt, M., Keil, M. et al., 2009 'On the suitability of MODIS time series metrics to map vegetation types in dry savanna ecosystems: A case study in the Kalahari of NE Namibia', Remote Sensing 1, 620-643. http://dx.doi.org/10.3390/rs1040620

Jürgens, N., Haarmeyer, D.H., Luther-Mosebach, J., Dengler, J., Finckh, M. \& Schmiedel, U. (eds.), 2010, Patterns at local scale: The BIOTA Observatories, Biodiversity in southern Africa, Klaus Hess Publishers, Göttingen \& Windhoek.

Kangombe, F.N., 2010, 'The vegetation of Omusati and Oshana regions, centralnorthern Namibia', MSc thesis, Department of Plant Sciences, University of Pretoria.

King, L.C., 1963, South African scenery, Hafner Publishing Company, New York.

Klaassen, E.S. \& Kwembeya, E.G. (eds.), 2013, 'A checklist of Namibian indigenous and naturalised plants', Occasional Contributions 5, National Botanical Research Institute, Windhoek. 
Leser, H., 1972, 'Geoökologische Verhältnisse der Pflanzengesellschaften in den Savannen des Sandveldes um den Schwarzen Nossob und Epukiro [Geo-ecological relationships of different plant communities in the sandveld savannas at the Black Nossob and Epukiro]', Dinteria 6, 1-44.

Lubbe, L.G., 2005, 'Towards an updated carrying capacity map for Namibia: A review of the methodologies currently used to determine carrying capacity in Namibia', Agricola 15, 33-39.

Mendelsohn, J. \& El Obeid, S., 2003, Sand and water. A profile of the Kavango region, Struik Publishers, Cape Town.

Mendelsohn, J., Jarvis, A., Roberts, C. \& Robertson, T., 2002, Atlas of Namibia, David Phillips Publishers, Cape Town.

Mendelsohn, J.M. \& El Obeid, S., 2002, Communal lands of eastern Namibia, RAISON and NNF, Windhoek.

Midgley, G., Hughes, G., Thuiller, W., Drew, G. \& Foden, W., 2005, 'Assessment of potential climate change impacts on Namibia's floristic diversity, ecosystem structure and function', Climate Change Research Group, South African National structure and function", Climate Change Research Group, South African National Biodiversity Institute for the Namibian Nation
Directorate of Environmental Affairs, Cape Town.

Mucina, L. \& Rutherford, M.C. (eds.), 2006, 'The vegetation of South Africa, Lesotho and Swaziland', Strelitzia 19, South African National Biodiversity Institute, Pretoria.

Müller, M.A.N., 2007, Grasses of Namibia, 2nd edn., Ministry of Agriculture, Water and Forestry, Windhoek.

Namibian Agricultural Resources Information System, 2001, 'Namibian Agricultural Resources Information System (NARIS), Agro-ecological zoning program', Ministry of Agriculture, Water and Rural Development, Windhoek.

Nambian Association of Community Based Natural Resource Managemen (CBNRM) Support Organisations, 2011, NACSO: Conservancies - By name viewed 18 December 2011, from http://www.nacso.org.na/SOC_profiles/ conservancylist.php

Roleček, J., Tichý, L., Zelený, D. \& Chytrý, M., 2009, 'Modified TWINSPAN classification in which the hierarchy respects cluster heterogeneity', Journal of Vegetatio Science 20, 596-602. http://dx.doi.org/10.1111/j.1654-1103.2009.01062.x

Schlesinger, W.H. \& Peterjohn, W.T., 1991, 'Processes controlling ammonia volatilization from Chihuahuan Desert soils', Soil Biological Biochemistry 23, 637642. http://dx.doi.org/10.1016/0038-0717(91)90076-V

Schlesinger, W.H., Raikes, J.A., Hartley, A.E. \& Cross, A.F., 1996, 'On the spatial pattern of soil nutrients in desert ecosystems', Ecology $77,364-374$. http://dx.doi. org $/ 10.2307 / 2265615$

Schlesinger, W.H., Reynolds, J.F., Cunningham, G.L., Huenneke, L.F., Jarell, W.M., Virginia, R.A. et al., 1990, 'Biological feedbacks in global desertification', Science 247, 1043-1048. http://dx.doi.org/10.1126/science.247.4946.1043

Scholes, R.J. \& Walker, B.H., 1993, An African savanna. Synthesis of the Nylsvley study, Cambridge University Press, Cambridge. http://dx.doi.org/10.1017/ CBO9780511565472

September, Z.M., 2006, Mapping the vegetation of the Sandveld Research Station in Namibia with the aid of remote sensing, BSc Hons mini dissertation, Department of Plant Sciences, University of Pretoria.

Seymour, C., 2001, Kalahari xeric savanna (Ecoregions/WWF), viewed 23 April 2010 from http://www.worldwildlife.org/ecoregions/at1309

Spriggs, A., 2001a, Kalahari Acacia-Baikiaea Woodlands (Ecoregions/WWF), viewed 23 April 2010, from http://www.worldwildlife.org/ecoregions/at0709

Spriggs, A., 2001b, Namibian savanna woodlands (Ecoregions/WWF), viewed 23 April 2010, from http://www.worldwildlife.org/ecoregions/at1316

Steynberg, F., 2011, 'Nuwe bewaringsgebiede open in Omahekestreek [New conservation areas open in Omaheke region]', Republikein, 01 July, viewed 17 December 2011, from http://www.republikein.com.na/politiek-ennasionale/toerisme-en-omgewingsake/nuwe-bewaringsgebiede-open-inomahekestreek.130727
Strohbach, B.J., 2001, 'Vegetation survey of Namibia', Journal of the Namibia Scientific Society $49,93-124$.

Strohbach, B.J., 2012, 'Providing relevant, useful information on Namibian vegetation types', Agricola 22, 7-39.

Strohbach, B.J. \& Jürgens, N., 2010, 'Towards a user-friendly vegetation map of Namibia: Ground truthing approach to vegetation mapping', in U. Schmiedel \& N. Jürgens (eds.), Patterns and processes at regional scale, Biodiversity in southern Africa, pp. 46-56, Klaus Hess Publishers, Göttingen.

Strohbach, B.J. \& Kangombe, F., 2012, 'National Phytosociological Database of Namibia', Biodiversity \& Ecology 4, 298. http://dx.doi.org/10.7809/b-e.00095

Strohbach, B.J. \& Petersen, A., 2007, 'Vegetation of the central Kavango woodlands in Namibia: An example from the Mile 46 Livestock Development Centre' South African Journal of Botany 37, 391-401. http://dx.doi.org/10.1016/ j.sajb.2007.03.002

Strohbach, B.J., Strohbach, M., Kutuahuripa, J.T. \& Mouton, H.D., 2004, 'A reconnaissance survey of the landscapes, soils and vegetation of the eastern communal areas (Otjiozondjupa and Omaheke regions), Namibia', unpublished report for the Desert Research Foundation of Namibia and the Programme, National Botanical Research Institute, Windhoek.

Strohbach, B.J. \& Kutuahuripa, J.T., submitted, 'Vegetation of the eastern communal conservancies in Namibia: II. Environmental drivers', Koedoe.

Thomas, D.S.G., 1988, 'The nature and depositional setting of arid and semi-arid Kalahari sediments, southern Africa', Journal of Applied Ecology 14, 17-26.

Thomas, D.S.G., Knight, M. \& Wiggs, G.F.S., 2005, 'Remobilization of southern African desert dune systems by twenty-first century global warming', Nature 435 , 1218-1221. http://dx.doi.org/10.1038/nature03717

Tichý, L., 2002, 'JUICE, software for vegetation classification', Journal of Vegetation Science 13, 451-453. http://dx.doi.org/10.1111/j.1654-1103.2002.tb02069.x

Tichý, L. \& Chytrý, M., 2006, 'Statistical determination of diagnostic species for site groups of unequal size', Journal of Vegetation Science 17, 809-818. http://dx.doi. org/10.1111/j.1654-1103.2006.tb02504.x

Van Eck, J.A.J., 2000, 'Control of gifblaar (Dichapetalum cymosum) at Oshimati', Agri-Info 5, 14-16.

Van Rooyen, M.W., Van Rooyen, N., Bothma, J. du P. \& Van den Berg, H.M., 2008 'Landscapes in the Kalahari Gemsbok National Park, South Africa', Koedoe 50, 99. http://dx.doi.org/10.4102/koedoe.v50i1.154

Vetter, S., 2001, Zambezian-Baikiaea Woodlands (Ecoregions/WWF), viewed 23 April 2010, from http://www.worldwildlife.org/ecoregions/at0726

Volk, O.H. \& Leippert, H., 1971, 'Vegetationsverhältnisse im Windhoeker Bergland, Südwestafrika [Vegetation relations in the Windhoek Mountainveld]', Journal der S.W.A. Wissenschaftliche Gesellschaft XXV, 5-44.

Wang, L., D'Odorico, P., Ringrose, S., Coetzee, S. \& Macko, S.A., 2007, 'Biogeochemistry of Kalahari sands', Journal of Arid Environments 71, 259-272. http://dx.doi. org/10.1016/j.jaridenv.2007.03.016

Weaver, L.C. \& Petersen, T., 2008, 'Namibia communal area conservancies', in Best practises in sustainable hunting. A guide to best practices from around the world,
$\mathrm{CIC}$ Technical Series, pp. 48-52, CIC-International Council for Game and Wildlife $\mathrm{CIC}$ Technical Series, pp. 48-52, CiC-1
Conservation and FAO, Budakeszi.

Weaver, L.C. \& Skyer, P., 2005, 'Conservancies: Integrating wildlife land-use options into the livelihood, development, and conservation strategies of Namibian communities', in Conservation and development interventions at the wildlife/ livestock interface: Implications for wildlife, livestock and human health. IUCN, Gland, Switzerland, Gland, Switzerland, paper
$08-17$ September 2003.

Weber, H.E., Moravec, J. \& Theurillat, J.P., 2000, 'International code of phytosociological nomenclature. 3rd edition', Journal of Vegetation Science 11, 739-768.

Westfall, R.H., Dednam, G., Van Rooyen, N. \& Theron, G.K., 1982, 'PHYTOTAB: A program package for Braun-Blanquet tables', Vegetatio 49, 35-37. http://dx.doi. org/10.1007/BF00051562 